University of Wollongong

Research Online

Faculty of Engineering and Information

Faculty of Engineering and Information

Sciences - Papers: Part A

Sciences

$1-1-2017$

\title{
Holistic sludge management through ozonation: a critical review
}

Galilee U. Semblante

University of Wollongong,gus193@uowmail.edu.au

Faisal I. Hai

University of Wollongong, faisal@uow.edu.au

Dionysios D. Dionysiou

University of Cincinnati

Kensuke Fukushi

University of Tokyo

William E. Price

University of Wollongong, wprice@uow.edu.au

See next page for additional authors

Follow this and additional works at: https://ro.uow.edu.au/eispapers

Part of the Engineering Commons, and the Science and Technology Studies Commons

Research Online is the open access institutional repository for the University of Wollongong. For further information contact the UOW Library: research-pubs@uow.edu.au 


\title{
Holistic sludge management through ozonation: a critical review
}

\author{
Abstract \\ This paper critically reviews the multidimensional benefits of ozonation in wastewater treatment plants. \\ These benefits include sludge reduction, removal of emerging trace organic contaminants (TrOC) from \\ wastewater and sludge, and resource recovery from sludge. Literature shows that ozonation leads to \\ sludge solubilisation, reducing overall biomass yield. Sludge solubilisation is primarily influenced by \\ ozone dosage, which, in turn, depends on the fraction of ozonated sludge, ozone concentration, and \\ sludge concentration. Additionally, sludge ozonation facilitates the removal of TrOCs from wastewater. \\ On the other hand, by inducing cell lysis, ozonation increases the chemical oxygen demand (COD) and \\ nutrient concentration of the sludge supernatant, which deteriorates effluent quality. This issue can be \\ resolved by implementing resource recovery. Thus far, successful retrieval of phosphorous from ozonated \\ sludge supernatant has been performed. The recovery of phosphorous and other resources from sludge \\ could help offset the operation cost of ozonation, and give greater incentive for wastewater treatment \\ plants to adapt this approach.

\section{Keywords} \\ holistic, ozonation:, management, critical, sludge, review \\ Disciplines \\ Engineering | Science and Technology Studies

\section{Publication Details} \\ Semblante, G. U., Hai, F. I., Dionysiou, D. D., Fukushi, K., Price, W. E. \& Nghiem, L. D. (2017). Holistic sludge \\ management through ozonation: a critical review. Journal of Environmental Management, 185 79-95.

\section{Authors} \\ Galilee U. Semblante, Faisal I. Hai, Dionysios D. Dionysiou, Kensuke Fukushi, William E. Price, and Long D. \\ Nghiem
}




\section{Holistic sludge management through ozonation: a critical review}

Galilee U. Semblante ${ }^{\text {a }}$, Faisal I. Hai ${ }^{\mathrm{a} *}$, Dionysios D. Dionysiou ${ }^{\mathrm{b}}$, Kensuke Fukushi ${ }^{\mathrm{c}}$, William E. Price $^{\mathrm{d}}$, and Long D. Nghiem ${ }^{\mathrm{a}}$

${ }^{a}$ Strategic Water Infrastructure Laboratory, School of Civil, Mining and Environmental Engineering, University of Wollongong, Wollongong, NSW 2522, Australia

${ }^{\mathrm{b}}$ Environmental Engineering and Science Program, University of Cincinnati, Cincinnati, OH 45221-0012, USA

c Integrated Research System for Sustainability Science, The University of Tokyo, 7-3-1 Hongo, Tokyo 113-8654, Japan

${ }^{\mathrm{d}}$ Strategic Water Infrastructure Laboratory, School of Chemistry, University of Wollongong,

Wollongong, NSW 2522, Australia

* Corresponding author:

Email: faisal@uow.edu.au,Ph: +61 242213054

\section{Abstract}


This paper critically reviews the multidimensional benefits of ozonation in wastewater treatment plants. These benefits include sludge reduction, removal of emerging trace organic contaminant (TrOC) from wastewater and sludge, and nutrient recovery from sludge. Literature shows that ozonation causes sludge solubilisation, reducing overall biomass yield. Sludge solubilisation is primarily influenced by ozone dosage, which, in turn, depends on the fraction of ozonated sludge, ozone concentration and sludge concentration. Additionally, sludge ozonation facilitates the removal of TrOCs from wastewater. On the other hand, by inducing cell lysis, ozonation increases the chemical oxygen demand (COD) and nutrient concentration of the sludge supernatant, which deteriorates effluent quality. This issue can be resolved by implementing resource recovery. Thus far, successful retrieval of phosphorous from ozonated sludge supernatant has been performed. The recovery of phosphorous and other resources from sludge could help offset the operation cost of ozonation, and give greater incentive for wastewater treatment plants to adapt this approach.

Keywords: cryptic growth; effluent quality; ozone; phosphorous recovery; sludge reduction

\section{Table of Contents}

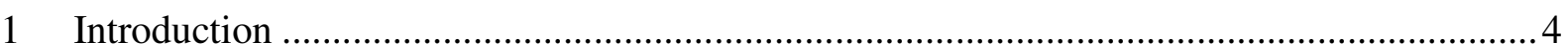

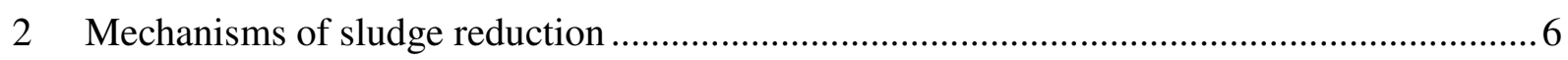




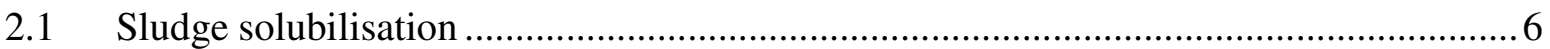

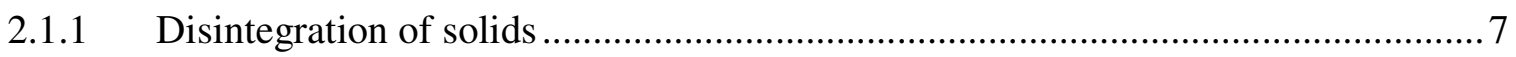

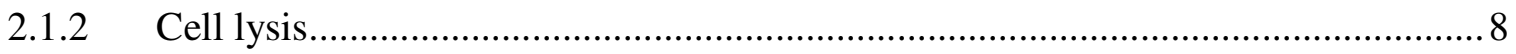

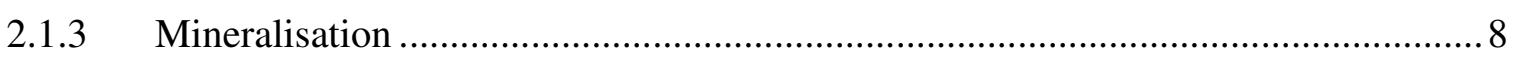

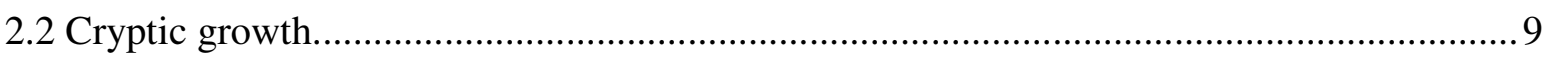

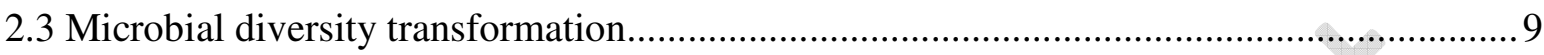

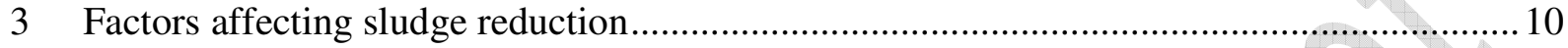

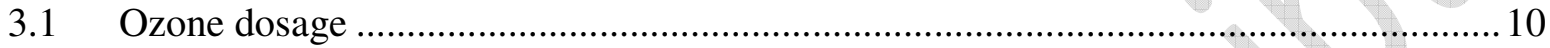

3.2 Ozone concentration, flow rate, and contact time ................................................... 11

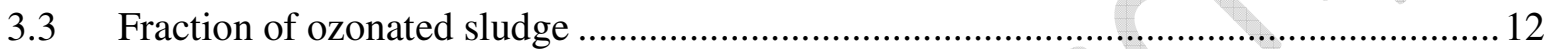

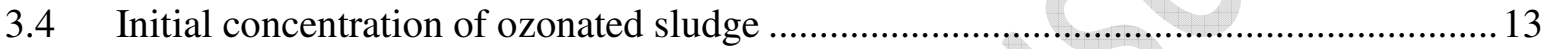

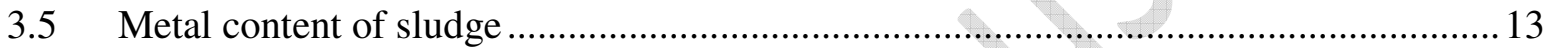

4 Effect of ozonation on effluent and sludge properties.................................................... 14

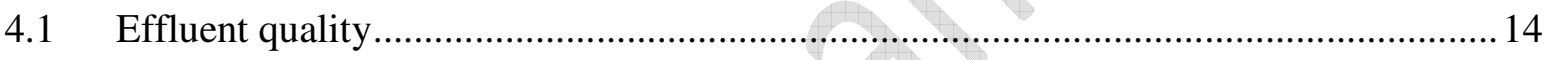

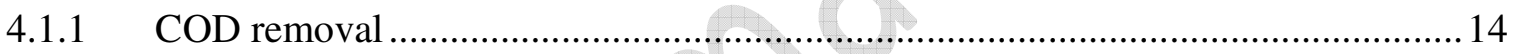

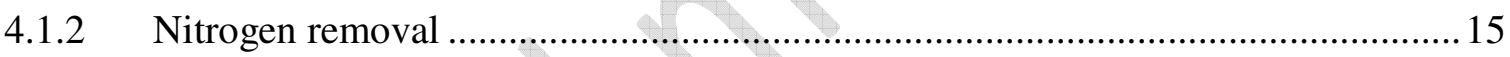

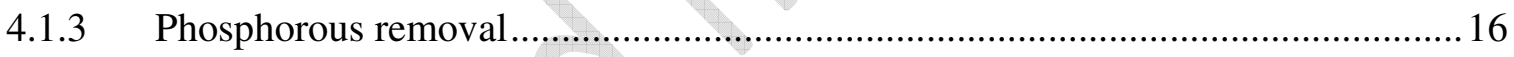

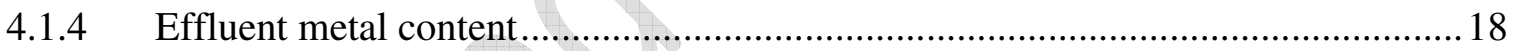

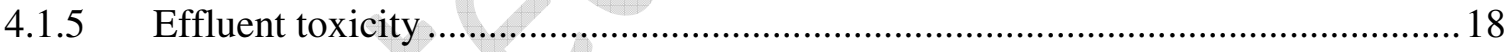

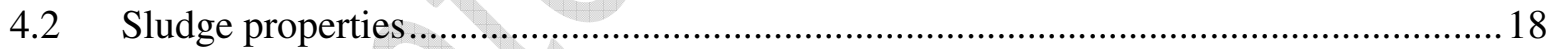

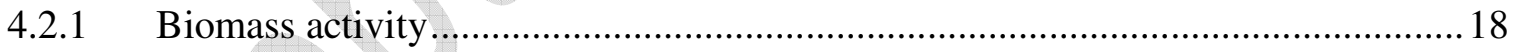

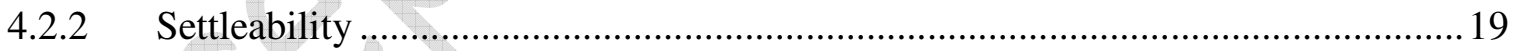

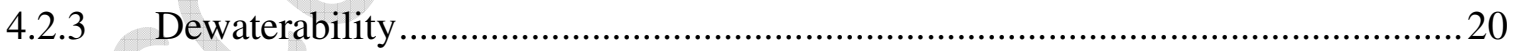

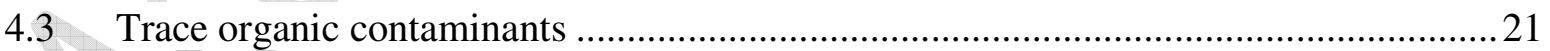

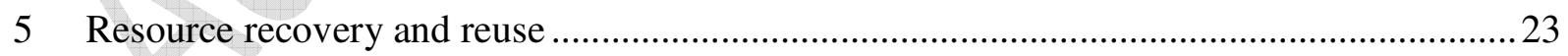

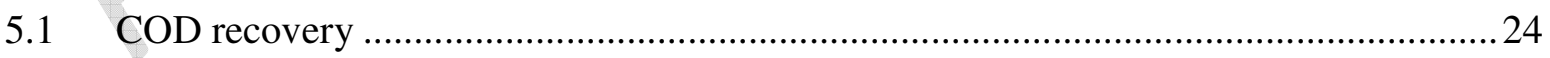

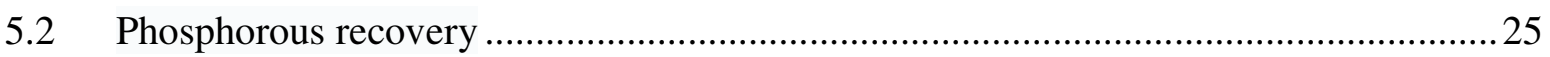

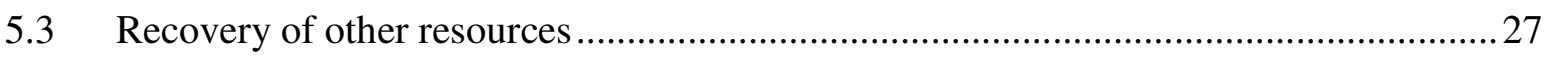

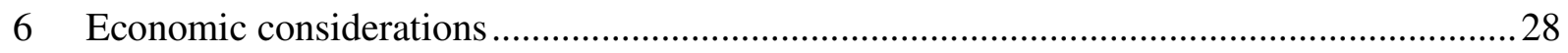

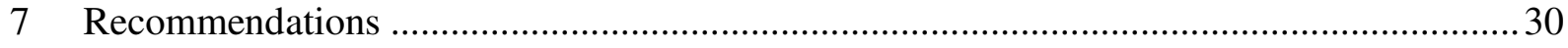

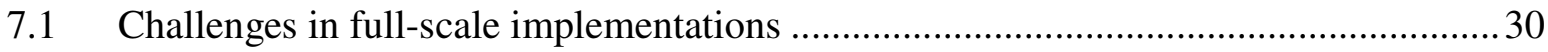




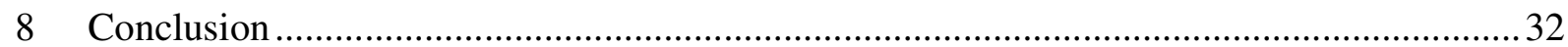

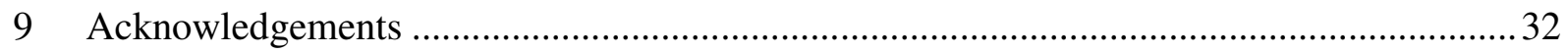

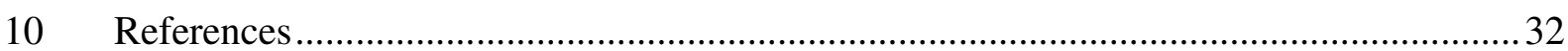

\section{Introduction}

Sludge production in wastewater treatment plants (WWTPs) is associated with two major issues namely (a) high cost and difficulty of sludge treatment and (b) limited options for ultimate sludge disposal. Sludge, in its original form, contains pathogens, emits foul odour, and attracts disease-causing vectors. Therefore, it must be transformed to a more benign state to avoid environmental and health impacts (Tchobanoglus et al., 2003). Multiple unit processes (e.g., dewatering, stabilisation, conditioning, and others) may be necessary to achieve the desired sludge quality. These processes entail equipment and operation cost, as well as technical challenges. For example, mechanical dewatering is difficult because water molecules have high affinity to biopolymers in sludge (Mowla et al., 2013). Moreover, sludge disposal options are decreasing over time with traditional options (ocean-dumping, landfilling, and incineration) being banned or curtailed because of stricter environmental standards (Fytili \& Zabaniotou, 2008). Recently, there has been an increasing emphasis on beneficial use of high-quality treated sludge as "biosolids" in agriculture. Biosolids are rich in organic matter (59-88\% w/v) and contain up to $55 \%$ carbon, $15 \%$ nitrogen, and $3 \%$ phosphorus, and therefore its reuse promotes the conservation of valuable resources (Tyagi \& Lo, 2013). However, not all agricultural lands can receive biosolids due to various considerations including accessibility to heavy vehicles, proximity to neighbors, and soil chemistry (Semblante et al., 2014a). Additionally, the use of biosolids is hindered by the occurrence of trace organic contaminants (TrOCs), such as pharmaceuticals, personal care products, hormones, pesticides, and industrial chemicals, which are recalcitrant to biological wastewater and sludge treatment. TrOCs may disrupt the endocrine system of wildlife and humans, causing developmental and reproductive abnormalities (larke $\underline{\text { \& Cummins, 2015; }}$ Semblante et al., 2015b). 
To sustainably cope with sludge production, a three-pronged approach to sludge management can be perceived: (i) reduction of biosolids production, (ii) remediation of conventional (e.g., pathogens, volatile solids, and heavy metals) and emerging contaminants, and (iii) recovery of resources. Reducing sludge production in biological wastewater treatment is a primary concern because it results in savings on sludge treatment, post-processing, handling, and transport (Foladori et al., 2010; Guo et al., 2013; Khursheed \& Kazmi, 2011; Spérandio et al., 2012; Wei et al., 2003). In other words, reducing sludge production is preferable to treating sludge that has already been produced. Various techniques have been employed for this purpose, including the optimisation of operating parameters (aeration and SRT) (Khursheed \& Kazmi, 2011; Wei et al., 2003), sludge disintegration by physical or advanced oxidation processes (AOPs) (Foladori et al., 2010), addition of chemicals (Feng et al., 2014; Liu, 2003), use of microbial predators such as protozoa, metazoa, and worms (Ghyoot \& Verstraete, 2000; Huang et al., 2007; Luxmy et al., 2001), and the oxic-settling-anoxic (OSA) process (Semblante et al., 2014a). The applicability of these techniques varies depending on sludge reduction, effect on wastewater treatment efficiency, effect on sludge properties, and cost (Table 1). Among the AOPs, ozonation is one of the most frequently used in water/wastewater treatment, specifically for effluent disinfection or polishing (von Gunten, 2003a). It is also effective for sludge reduction, and has been successfully applied in WWTPs in Japan and some European Union countries (Paul et al., 2012). Additional benefits of ozonation include the removal of pathogens and volatile solids during sludge treatment (e.g., aerobic or anaerobic digestion). Furthermore, research has shown that ozonation directly removes or enhances the biodegradation of emerging contaminants (Esplugas et al., 2007; Umar et al., 2013), and facilitates the release and recovery of nutrients from sludge (Qiang et al., 2015; Saktaywin et al., 2005). Therefore, ozonation has the potential to fulfill the requirements of sustainable sludge management.

This paper is a critical review of the recent advances in sludge management through ozonation. Significant research effort has been devoted to the application of ozonation in sludge reduction (Chu et al., 2009b) or removal of emerging contaminants (Gerrity \& Snyder, 2011), but there is only a few studies linking the two together (Qiang et al., 2015; Tsuno et al., 2008). Meanwhile, the use of ozonation in resource recovery is an emerging topic that is worthy of further investigation (Qiang et al., 2015; Saktaywin et al., 2005). The limitations of ozonation, such as 
high operation cost and potential impact on effluent quality, are evaluated to determine ongoing challenges and future research directions.

\section{Mechanisms of sludge reduction}

Sludge reduction by ozonation can be performed by applying ozone $\left(\mathrm{O}_{3}\right)$ to return activated sludge (RAS) prior to its recirculation to the main bioreactor (Figure 1). The primary mechanism of sludge reduction in this process is sludge solubilisation followed by "cryptic growth". The solubilisation of particles and destruction of cells results in the release of biodegradable and nonbiodegradable materials to the sludge supernatant (Section 2.1). Cryptic growth occurs when ozonated sludge is returned to the aeration tank wherein the biodegradable fraction is consumed by healthy microorganisms (Section 2.2). The continuous cycle of sludge solubilisation-cryptic growth results in a net reduction of sludge. Additionally, ozonation may affect microbial diversity of sludge, which has implications on biomass growth and sludge production rates (Section 2.4).

\section{[Figure 1]}

\subsection{Sludge solubilisation}

The solubilisation of sludge through ozonation involves a series of decomposition reactions including solids disintegration, cell lysis, and mineralisation (Chu et al., 2009b). These phenomena have been studied at different ozone dosages, defined as

Ozone dosage $=\frac{\text { Mass of ozone }}{\text { Mass of sludge }}$

Sludge destruction efficiency can be expressed through chemical oxygen demand (COD) solubilisation, which has been defined as:

$\operatorname{COD}$ solubilisation $(\%)=\frac{S C O D_{\text {after ozone }}-S C O D_{\text {before ozone }}}{T C O D_{\text {before ozone }}-S C O D_{\text {before ozone }}} \times 100$ Equation 2 
where SCOD and TCOD are soluble (supernatant) and total (mixed liquor) COD, respectively (Bougrier et al., 2006; Demir \& Filibeli, 2012). Researchers report that 10-60\% of COD is solubilised due to ozonation at 10-160 $\mathrm{mg} \mathrm{O}_{3} / \mathrm{g}$ total suspended solids (TSS) (Bougrier et al., 2006; Demir \& Filibeli, 2012; Saktaywin et al., 2005; Zhang et al., 2009). Another approach to assess sludge destruction is to monitor nitrogen and phosphorous, which are released to the supernatant during cell lysis. For instance, Arakawa et al., (2011) reported that ozonation at 23 $\mathrm{mg} \mathrm{O}_{3} / \mathrm{g}$ TSS in a full-scale plant resulted in $19 \%$ sludge destruction measured in terms of TN solubilisation.

\subsubsection{Disintegration of solids}

Sludge ozonation can result in $10-80 \%$ total solids (TS) reduction depending on ozone dosage (15-60 mg O $_{3} / \mathrm{g}$ TS), feed type, and sludge composition (Park et al., 2003; Richardson et al., 2009; Yang et al., 2013). The disintegration of solids occurs in the breakdown of sludge flocs. Sludge flocs are microbial aggregates bound together by extracellular polymeric substances (EPS), which are proteins, carbohydrates, humic acids, and other organic molecules that provide structural support protection to clusters of microorganisms (Liu \& Fang, 2003). Research found that ozonation may cause EPS destruction (Chu et al., 2009b; Yan et al., 2009). The loss of EPS renders the microorganisms vulnerable to oxidative attack (Chu et al., 2009b; Yan et al., 2009), and can increase the biodegradability of sludge (Semblante et al., 2015a).

Floc destruction can be assessed in terms of change in sludge floc size (Table 1). Some studies found that increasing ozone dosage decreased sludge floc size, which pertains to floc destruction (Demir \& Filibeli, 2012; Park et al., 2003). By contrast, other studies found that increasing ozone dosage enhanced (Song et al., 2003) or did not change (Bougrier et al., 2006; Zhang et al., 2009) floc size. According to Song et al. (2003), ozonated sludge had larger particles $(60 \mu \mathrm{m})$ than non-ozonated sludge $(30 \mu \mathrm{m})$ due to the coagulation and eventual re-flocculation of solids after ozonation. Discrepancies between different studies are possibly due to variations in sludge properties and experimental conditions (e.g., range of ozone dosages).

[Table 1] 


\subsection{2 $\quad$ Cell lysis}

Ozonation can rupture the cell membrane, causing cell death and releasing intracellular materials ( 2003). Sludge, which is composed of a broad range of microorganisms, behaves analogously. Yan et al., (2009b) and Chu et al., (2009a) both found that sludge ozonation at $20 \mathrm{mg} \mathrm{O}_{3} / \mathrm{g}$ TSS resulted in cell lysis and release of deoxyribonucleic acid (DNA) and adenosine triphosphate (ATP) to the supernatant. Ozonation causes an overall decrease in microbial respiratory activity as measured by specific oxygen uptake rate (SOUR) (Albuquerque et al., 2008; Nie et al., 2014). Individual activities of microbial groups could vary as well. For example, ozonation at $30-40 \mathrm{mg}$ $\mathrm{O}_{3} / \mathrm{g}$ TSS decreased the activity of both polyphosphate-accumulating-organisms (PAOs) and heterotrophic bacteria by $80 \%$ (Saktaywin et al., 2005). Meanwhile, ozonation at $50 \mathrm{mg} \mathrm{O} / \mathrm{g} \mathrm{SS}$ decreased the activity of nitrifying bacteria by only $20 \%$ (Saktaywin et al., 2005). Certain microorganisms in sludge are highly resistant to ozonation. For instance, Yan et al., (2009) observed that gram-negative bacteria that are structured in tetrads, sheets, or clusters (e.g., Azonexus and Ferribacteria) survive even under high ozone dosage (100 $\mathrm{mg} \mathrm{O}_{3} / \mathrm{g}$ TSS) probably because their cellular arrangement gives protection from oxidative attack. Protozoa such as Giardia lamblia and Cryprosporidium parvum, which are used as indicator microorganisms in drinking water disinfection, also have tendency to survive exposure to ozone (von Gunten, $\underline{2003 b})$.

Ozonation at dosages greater than the threshold for cell lysis causes a decline in sludge solubilisation due to the formation of "radical scavengers." For instance, ozonation at $100 \mathrm{mg}$ $\mathrm{O}_{3} / \mathrm{g}$ TSS resulted in the conversion of lysates (products of cell lysis) into volatile fatty acids

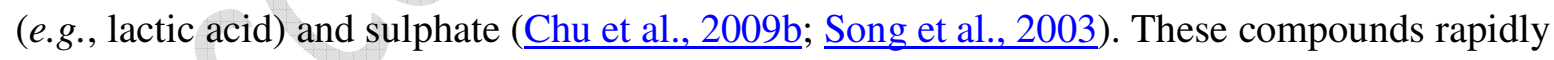
consume radicals and interfere with sludge reduction (Chu et al., 2009b; Song et al., 2003), and have potential to decrease sludge solubilisation efficiency. Radical scavengers are discussed in more detail in Section 3.1.

\subsubsection{Mineralisation}

Several studies have shown that $5-26 \%$ of TS can be mineralised at ozone dosages of $18-50 \mathrm{mg}$ $\mathrm{O}_{3} / \mathrm{g}$ TSS (Chu et al., 2009b; Goel et al., 2003). Included in this mineralized fraction are the inert or non-biodegradable solids (Zhang et al., 2009). Inert solids could comprise $25-50 \%$ of the TSS 
of primary or secondary sludge depending on influent characteristics and operation conditions (Turovskiy \& Mathai, 2005). The mineralisation (Zhang et al., 2009) or conversion of inert solids into more biodegradable forms (Saktaywin et al., 2005; Tsuno et al., 2008) further contributes to the overall decrease of sludge mass.

\subsection{Cryptic growth}

Cryptic growth occurs when ozonated sludge, which has high concentration of SCOD, is recirculated to the aeration tank. Microorganisms in the aeration tank utilise the biodegradable COD as secondary external substrate for growth and cell maintenance. This process converts ozone-solubilized sludge into respiration products (e.g., $\mathrm{CO}_{2}$ and $\mathrm{N}_{2}$ ), and therefore a net reduction of sludge occurs. Cryptic growth can be induced using other technologies that destroy biomass including ultrasonic, thermal, and mechanical treatment (Foladori et al., 2010; Semblante et al., 2014a). The impact of sludge solubilisation-cryptic growth mechanism on sludge reduction is usually evaluated using sludge yield, which is discussed in conjunction with factors affecting system performance (e.g., ozone dosage, concentration, and others) in Section 3.

\subsection{Microbial diversity transformation}

The continuous ozonation of RAS have great potential to transform the microbial diversity of sludge. Previous studies have demonstrated that advanced oxidation or other types of sludge pretreatment results in notable shifts in microbial community structure. For instance, ultrasonic (Cho et al., 2016), Fenton ( $\underline{\text { Su et al., 2016) }}$, or heat (Kang et al., 2012) pre-treatment of sludge can selectively enrich certain anaerobic bacterial species and consequently improved methanogenic activity and/or wastewater treatment efficiency. However, there have been very few studies on the impact of ozonation on microbial diversity (Chiellini et al., 2014; Yan et al., 2009). Yan et al., (2009) used polymerase chain reaction-denaturing gradient gel electrophoresis (PCR-DGGE) analysis and microscopic bacterial counting to compare ozonated (150 $\mathrm{mg} \mathrm{O}_{3} / \mathrm{g}$ TSS) and non-ozonated laboratory-scale bioreactors. They observed that the ozonated bioreactor contained a greater diversity of bacteria, protozoa, and metazoa compared to the non-ozonated bioreactor. Protozoa and metazoa are bacterial predators that can be selectively cultivated to reduce sludge (Luxmy et al., 2001; Semblante et al., 2014b). Chiellini et al., (2014) analysed full-scale aerobic digesters receiving ozonated and non-ozonated WAS using terminal restriction 
fragment length polymorphism (T-RFLP) analysis of the 16S rRNA gene. At low dosage (0.3 $\mathrm{mg} \mathrm{O}_{3} / \mathrm{g}$ TSS), there was negligible sludge reduction and the ozonated digester had greater microbial diversity than the non-ozonated digester probably due to the proliferation of bacteria that can withstand oxidative attack. However, at high dosage (2.1-2.3 $\mathrm{mg} \mathrm{O}_{3} / \mathrm{g}$ TSS), there was 10-20\% reduction in VSS and TSS and the ozonated and non-ozonated digester had similar microbial diversity due to an uniform elimination of different groups of bacteria. The study of Chiellini et al., (2014) showed evidence of biomass destruction-cryptic growth mechanism, but it was unable to clarify the role of microbial diversity on sludge reduction. However, a direct comparison of Yan et al., (2009) and Chiellini et al., (2014) is not possible due to difference in scale, configuration, and reactor type between the two studies. Further investigation is required to establish the potential linkage between ozonation, sludge reduction, and microbial community transformation.

\section{Factors affecting sludge reduction}

\subsection{Ozone dosage}

Ozone dosage is the primary factor affecting sludge solubilisation (Section 2.1), and therefore it greatly influences sludge reduction efficiency. Sludge reduction in secondary treatment tanks is usually assessed by measuring the change in sludge yield, which is defined as

Sludge yield $=\frac{\text { Mass of sludge produced }}{\text { Mass of substrate consumed }}$

Equation 3

Several studies report that ozone dosage within the range of 30-50 $\mathrm{mg} \mathrm{O}_{3} / \mathrm{g}$ TSS applied to the entirety or a fraction of RAS resulted in $20-100 \%$ reduction of sludge yield (Table 2 ). The optimum ozone dosage is usually determined through an empirical approach, and is additionally influenced by ozonation conditions such as flow rate and contact time (discussed in Section 3.2), and sludge characteristics such as MLSS (discussed in Section 3.4) or metal concentration (discussed in Section 3.5) (Figure 3). In general, operation at dosages higher than the sitespecific optimum range deteriorates sludge reduction rate possibly due to the formation of intermediates and by-products that serve as radical scavengers (Section 2.1.2). 
[Table 2]

The mathematical model of Isazadeh et al., (2014) based on International Water AssociationActivated Sludge Model 3 (IWA-ASM3) predicted that ozonation at dosages lower than the optimum value could induce cell lysis, but does not result in significant sludge solubilisation. This is in agreement with the study of Meng et al., (2015), which showed that extensive cell lysis was not the most important factor affecting sludge reduction. Meng et al., (2015) observed that although a slight degree of cell lysis occurred at low ozone dosage (11 $\left.\mathrm{mg} \mathrm{O}_{3} / \mathrm{g} \mathrm{MLSS}\right)$, large amounts of macromolecules and nutrients were released into the supernatant. Increasing ozone dosage to $90 \mathrm{mg} \mathrm{O}_{3} / \mathrm{g}$ MLSS increased cell lysis, but it decreased the release of macromolecules. Clearly, the application of high ozone dosage results in the oxidization of macromolecules in the supernatant rather than sludge solubilisation (Meng et al., 2015). These findings imply that it is not beneficial to aim for extensive cell lysis by applying high ozone dosages; rather ozone dosage must be determined based on sludge solubilisation efficiency.

\subsection{Ozone concentration, flow rate, and contact time}

High sludge reduction efficiency can be achieved with proper adjustment of ozone concentration, flow rate, and contact time. A wide range of ozone concentrations and flow rates have been reported in the literature (Table 3), but only a few studies have systematically investigated the relationship of the operational parameters on sludge reduction. For example, in a series of batch tests, Manterola et al., (2008) showed that increasing the flow rate of gas (e.g., from 350-940 L/h) and decreasing ozone concentration (e.g. from 150 to $50 \mathrm{mg} / \mathrm{L}$ ) increased COD solubilisation by up to 50\% (Table 3). Similarly, Zhou and Smith (2000) reported that ozone flow rate was the most important factor affecting the mass transfer of ozone into aqueous solutions. Gardoni et al., (2015) also showed that ozone concentration was inversely proportional to COD solubilisation in an ozone reactor using single and multiple Venturi injectors. These studies imply that sludge solubilisation is favoured by low ozone concentration and high ozone flow rate (Gardoni et al., 2015; Manterola et al., 2008). Accordingly, sludge reduction can be achieved with minimum strain on the ozone generator, which ultimately helps reduce the operation cost of the system (discussed in Section 6).

[Table 3] 
Knowing the effect of the ozone-sludge contact time on sludge reduction is critical in selecting the hydraulic retention time (HRT) and/or volume of the ozonation vessel. The contact times reported in literature (Table 3) are kept relatively short (e.g., 5-30 min) because ozone and radicals have very high reactivity and short half-lives. Manterola et al., (2008) did not observe any significant change in the soluble COD of sludge after ozonation at different HRTs (10-57 min), which meant that a short HRT (e.g., $10 \mathrm{~min}$ ) was sufficient to reach maximum sludge solubilisation. Other studies caution that increasing contact time may in fact reduces sludge reduction due to the formation of radical scavengers (Naso et al., 2008; Subha \& Muthukumar, 2012). Naso et al., (2008) varied the ozone contact time (0-30 min) at different ozone dosages, and found that $30 \mathrm{~min}$ resulted in the maximum COD solubilisation at the ozone range of 0.05 $0.07 \mathrm{~g} \mathrm{O}_{3} / \mathrm{g}$ SS. However, a contact time of $20 \mathrm{~min}$ was adequate to achieve maximum COD solubilisation when ozone dosage was $0.37 \mathrm{~g} \mathrm{O}_{3} / \mathrm{g}$ SS. Similarly, Subha and Muthukumar (2012) observed that increasing contact time from 1 to 12 minutes maximized VSS reduction to $81 \%$, but beyond this period the VSS reduction decreased to $32 \%$ due to the activity of radical scavengers.

\subsection{Fraction of ozonated sludge}

The fraction or amount of sludge that is ozonated is an important operational parameter because it determines ozonation requirements, yet only a few studies have systematically investigated its effect on sludge reduction efficiency (Albuquerque et al., 2008; Romero et al., 2015).

Albuquerque et al., (2008) showed that increasing the fraction of ozonated sludge from 10 to $20 \%$, while maintaining a RAS ratio at $1 / 3$, decreased the sludge yield of conventional activated sludge (CAS) by approximately $8 \%$. On the other hand, maintaining the fraction of ozonated sludge at $20 \%$ and increasing the RAS ratio from $1 / 3$ to $2 / 3$ decreased the sludge yield by $23 \%$. These results are corroborated by the full-scale study of Romero et al., (2015) which reported that that increasing the amount of ozonated sludge from $500 \mathrm{MLVSS} / \mathrm{h}$ to $750 \mathrm{~kg} \mathrm{MLVSS} / \mathrm{h}$ increased SCOD from 20 to $40 \mathrm{mg} / \mathrm{L}$. These studies show that the fraction or amount of ozonated sludge is directly proportional to sludge solubilisation and consequently, to sludge reduction efficiency. Nonetheless, various studies that ozonated the same fraction of RAS (20\%) at different ozone dosages (1-80 $\mathrm{mg} \mathrm{O}_{3} / \mathrm{g}$ solids) resulted in a wide range of sludge reduction efficiencies (17-40\%) (Albuquerque et al., 2008; Demir \& Filibeli, 2014; Dytczak \& 
Oleszkiewicz, 2008; Gardoni et al., 2011). This implies that ozone dosage has greater relevance on system performance than the fraction or amount of ozonated sludge. Furthermore, increasing the fraction or amount of ozonated sludge may lead to the deterioration of effluent quality (Albuquerque et al., 2008; Romero et al., 2015). For example, Albuquerque et al., (2008) showed that increasing the fraction of ozonated RAS from 10 to $20 \%$ increased the organic loading to CAS, which led to a $10 \%$ decrease in the COD removal efficiency of CAS (Albuquerque et al., 2008). Romero et al., (2015) reported that effluent COD increased by 9 $\mathrm{mg} / \mathrm{L}$ for every $1 \mathrm{~kg}$ of MLVSS that was ozonated. The effect of sludge ozonation on effluent COD and its potential implications on wastewater treatment is discussed in more detail in Section 4.1.1.

\subsection{Initial concentration of ozonated sludge}

The sludge concentration of the main bioreactor is maintained to achieve a specific food-tomicroorganism ratio that ensures COD removal and prevents washout of solids in the effluent. Sludge concentration may also impact solubilisation efficiency, especially under low ozone dosages (Manterola et al., 2008). The study of Manterola et al., (2008) showed that when ozone dosage was 5-20 $\mathrm{mg} \mathrm{O}_{3} / \mathrm{g}$ TSS, sludge with low initial TSS (4 g/L) was solubilized faster than sludge with high initial TSS ( $9 \mathrm{~g} / \mathrm{L})$. However, when ozone dosage was at the range of 20-35 mg $\mathrm{O}_{3} / \mathrm{g}$ TSS, the TSS of sludge ceased to become important and sludge with either low or high TSS were solubilized at similar rates. This suggests that reactors with low sludge concentration (e.g., $4 \mathrm{~g} / \mathrm{L})$ are potentially more amenable to ozone treatment compared to those with high sludge concentration (i.e., $>9 \mathrm{~g} / \mathrm{L}$ ).

The effect of sludge concentration on reduction was assessed by comparing various laboratoryand full-scale reports (Figure 4). The collected data, however, do not reveal a clear pattern. This is mainly because a wide range of ozone dosages (1-100 $\mathrm{mg} \mathrm{O}_{3} / \mathrm{g}$ SS, DS or TSS) has been applied across different studies. In general, there have been far fewer full-scale implementations (Figure 4). It is worthwhile to determine solubilisation efficiency of highly concentrated sludge and the implications of sludge concentration on ozone demand.

\subsection{Metal content of sludge}

The concentration of metal in sludge largely depends on feed type. Industrial wastewater may have a high metal content, whereas domestic wastewater contains various metals in trace 
concentrations ( $\mu \mathrm{g} / \mathrm{L}$ to few $\mathrm{mg} / \mathrm{L}$ ) (Tchobanoglus et al., 2003). Ozonation converts metals into their respective higher oxidation state that is insoluble in water. As such, oxidation has been applied to remove metals such as iron and manganese from high-strength waste streams through precipitation followed by physical separation (Seo et al., 2010).

Certain metals can inhibit sludge solubilisation by ozonation. Sui et al. (2011) observed that calcium and magnesium had negligible impact on sludge solubilisation, but iron prevented the destruction of sludge flocs. Sludge with high iron content (80-120 mg Fe/g SS) had 50\% lower solubilisation efficiency than sludge with low iron (4.7-7.4 mg Fe/SS). The mechanism for this inhibition warrants further investigation, especially since the inhibitory effect of iron $\left(\mathrm{Fe}^{3+}\right)$ has also been observed in OSA, a process that reduces sludge through aerobic/anoxic cycling. Dosing iron to sludge prevented EPS disintegration under anoxic conditions, and consequently decreased OSA performance (Semblante et al., 2016). On the contrary, another study successfully added iron $\left(\mathrm{Fe}^{2+}\right)$ to sludge to induce the Fenton reaction $\left(\mathrm{Fe}^{2+}+\mathrm{H}_{2} \mathrm{O}_{2} \rightarrow \mathrm{Fe}^{3+}+\right.$ $\cdot \mathrm{OH}+\mathrm{OH}^{-}$and $\mathrm{Fe}^{3+}+\mathrm{H}_{2} \mathrm{O}_{2} \rightarrow \mathrm{Fe}^{2+}+\cdot \mathrm{OOH}+\mathrm{H}^{+}$) under acidic conditions. This reaction was stimulated using ultrasonication, and was found to facilitate cell lysis and mineralisation of soluble organic substances (Rai et al., 2013). The inhibitory effect of iron on sludge reduction was negated by the reduction of $\mathrm{Fe}^{3+}$, that prevented its interaction and binding with sludge flocs.

\section{Effect of ozonation on effluent and sludge properties}

\subsection{Effluent quality}

\subsubsection{COD removal}

The effect of ozonation on effluent quality is an important consideration when applying this technology in wastewater treatment systems. Generally, ozonation increases effluent COD due to sludge solubilisation (Section 2.1). In spite of this, many studies demonstrate that the overall COD removal efficiency was unaffected (Demir \& Filibeli, 2014; $\underline{\text { Huysmans et al., 2001; Naso }}$ et al., 2008; Nie et al., 2014; Paul et al., 2012; Richardson et al., 2009; Song et al., 2003; Tsuno et al., 2008) or underwent a minor decrease (5-10\%) (Albuquerque et al., 2008; Nagare et al., 2008; Qiang et al., 2015), and therefore effluent COD was maintained at satisfactory levels. This was because the majority of the solubilized COD was biodegradable, and was rapidly consumed 
when ozonated sludge was returned to the aerobic reactor (Dytczak \& Oleszkiewicz, 2008; Nagare et al., 2008). This was corroborated by studies showing that the BOD/COD ratio of sludge remained the same or increased depending on ozone dosage (Deleris et al., 2002; Gommers et al., 2007; Labelle et al., 2011; Nagare et al., 2008). Nonetheless, a careful assessment of the remaining refractory fraction that persisted in both biological and oxidative treatment must be performed, especially when effluent is discharged in sensitive water bodies or routed towards re-use applications (Nagare et al., 2008). The refractory fraction may include TrOCs that may have serious impact on wildlife and human health as discussed in Section 4.3.

\subsubsection{Nitrogen removal}

Sludge solubilisation results in the release of nitrogenous species, mostly in the form of organic nitrogen (Déléris et al., 2000; Qiang et al., 2015; Sui et al., 2011). In sludge, ozonation can further oxidize a fraction of the released organic nitrogen (e.g., 30\%) to ammonia (Deleris et al., 2002; Sui et al., 2014). In other matrices such as seawater, further conversion of ammonia to nitrite and then nitrate or directly to nitrate through ozonation can take place (Schroeder et al., 2011). However, the occurrence of these reaction pathways has not been confirmed in sludge.

The fate of nitrogen is dependent on ozonation conditions. For instance, Kondo et al., (2009) reported that increasing the amount of ozonated sludge (3.4-8.4 L/day) increased organic carbon loading and dissolved oxygen competition between nitrifying and heterotrophic bacteria. This phenomenon consequently decreased nitrification efficiency, which increased the concentration of ammonia (Kondo et al., 2009). Sui et al., (2014) observed that adjusting ozone concentration and flow rate could vary the conversion rate of solubilized organic nitrogen to ammonia. Ozone concentrations and flow rate had inverse and direct relationship with ammonia formation, respectively. This implies that minimizing ozone concentration is favourable in minimizing both the discharge of ammonia and ozone demand (Sui et al., 2014).

The recirculation of ozonated RAS, which may have high nitrogen and oxygen content, can decrease nitrogen removal efficiency of the main bioreactor/s. In one study, the release of organic nitrogen increased the Total Kjeldal Nitrogen (TKN) of the effluent by $10 \%$ (Richardson et al., 2009). Other studies report 10-20\% decrease in total nitrogen (TN) removal efficiency 
(Table 4) upon ozonation at 20-100 $\mathrm{mg} \mathrm{O}_{3} / \mathrm{g}$ SS or TSS due to inhibition of nitrification and/or denitrification reactions (Gardoni et al., 2011; Meng et al., 2013; Naso et al., 2008). The adverse effect of ozonation on nitrification was observed by Naso et al., (2008). In their study, ozone destabilized nitrifying bacteria and consequently decreased the TN removal efficiency of a sequencing batch reactor(SBR). The susceptibility of nitrifiers to ozonation was also observed by Bohler and Siegrist (2004). Meanwhile, Gardoni et al., (2011) reported negative impact of ozonation on denitrification. The recirculation of oxygen-rich ozonated sludge in an anoxic/aerobic system prevented facultative denitrifying bacteria from utilizing nitrate as ozone acceptor, which resulted in reduced denitrification efficiency (Gardoni et al., 2011). Similarly, Meng et al., (2013) observed nitrate accumulation in the aerobic phase of an ozonated anaerobic/anoxic/aerobic reactor, which could be linked to inhibition of denitrification in the preceding anoxic phase. The impact of ozone on denitrification was not explored in detail, but there is a possibility that the high inorganic nitrogen load in ozonated sludge impacted denitrifying bacteria (Tchobanoglus et al., 2003).

[Table 4]

Ozonation can increase soluble nitrogen concentration, however, many studies have also shown that adequate overall TN removal efficiency of the main bioreactor/s can still be achieved (Arakawa et al., 2011; Nie et al., 2014; Qiang et al., 2015; Song et al., 2003; Sui et al., 2014; Tsuno et al., 2008). Stable reactor performance could be achieved when sludge acclimatizes to continuous ozonation (Qiang et al., 2015; Sui et al., 2014). This phenomenon is especially evident in the study of Sui et al. (2014), which showed that nitrification in an anaerobic/aerobic reactor failed upon introducing ozone to the system. However, it was eventually restored without intervention, and the nitrogenous compounds solubilized by ozone were removed via nitrification/denitrification (Sui et al., 2014). Similarly, Qiang et al., (2015) emphasized that the nitrogen removal efficiency of an anaerobic/anoxic/aerobic process remained unchanged by sludge ozonation. The system was able to cope with surplus nitrogen produced during sludge ozonation, and the effluent TN concentration was maintained at acceptable levels (10 mg/L).

\subsubsection{Phosphorous removal}

Enhanced biological phosphorous removal (EBPR) involves the treatment of sludge under aerobic and anaerobic conditions wherein PAOs expel and consume orthophosphate, 
respectively. Phosphorous is separated from wastewater when phosphorous-rich sludge is withdrawn. Ozonation has potential to adversely affect phosphorous removal efficiency in two ways. Firstly, sludge solubilisation releases organic and inorganic phosphorous (Saktaywin et al., 2005) that could reduce effluent quality or adversely affect biological phosphorous removal. For example, Saktaywin et al., (2005) reported that orthophosphate and acid-hydrolyzable phosphorous were released at the concentration of 6 and $12 \mathrm{mg} \mathrm{P} / \mathrm{L}$, respectively, at the ozone dosage of $13 \mathrm{mg} \mathrm{O}_{3} / \mathrm{g} \mathrm{SS}$ (i.e., $15 \mathrm{mg} \mathrm{O}_{3} / \mathrm{g}$ particulate $\mathrm{COD}$ ). Other studies report that the majority (e.g., 80\%) of solubilized phosphorous was in the form of orthophosphate (Kondo et al., 2009; Qiang et al., 2015). Secondly, decreasing sludge withdrawal allows phosphorous to accumulate in the reactors (Gardoni et al., 2011; Nie et al., 2014; Qiang et al., 2015) (Table 4). Nie et al., (2014) observed that ozonation ceased production of excess sludge in CAS process, making sludge withdrawal unnecessary. In absence of sludge withdrawal, however, phosphorous accumulation occurred and TP removal decreased from approximately 80 to $70 \%$. Similarly, Qiang et al., (2015) reported that ozonation reduced excess sludge of an anaerobic/anoxic/aerobic system but gradually increased effluent TP concentration from 0.1 to 2 $\mathrm{mg} / \mathrm{L}$. On the other hand, Meng et al., (2013) reported negligible impact of ozonation on effluent phosphorous concentration of an anaerobic/anoxic/aerobic reactor. They attributed this finding to the low ozone dosage (2-20 $\mathrm{mg} \mathrm{O}_{3} / \mathrm{mg}$ TSS) in their study, which potentially caused minimal release of phosphorous. Indeed relatively high ozone concentrations (e.g., $>30 \mathrm{O}_{3} / \mathrm{mg} \mathrm{TSS}$ ) resulted in extensive sludge solubilisation and phosphorous release (Gardoni et al., 2011; Saktaywin et al., 2005). Additionally, previous studies reported that reactors acclimatized to nitrogen-rich sludge and were able to maintain low effluent TN concentration (Section 4.1.2).

In some cases, the drastic increase in effluent TP concentration due to ozonation necessitated post-treatment (e.g., coagulation) to meet discharge standards (Gardoni et al., 2011). An alternative approach is to capitalize on biomass solubilisation to enable phosphorous recovery. Arakawa et al., (2011) reportedly recovered phosphorous from the effluent of ozonated anaerobic/anoxic/aerobic system by chemical precipitation and consequently maintained the final TP discharge below $1 \mathrm{mg} / \mathrm{L}$. Several studies have demonstrated that highly concentrated waste streams, such as ozonated sludges and digestates, are ideal targets for nutrient recovery schemes (Qiang et al., 2015; Tsuno et al., 2008) which will be discussed in greater detail in Section 5.1. 


\subsubsection{Effluent metal content}

Generally, ozonation facilitates metal precipitation (Section 3.5). However, it can also decrease mixed liquor $\mathrm{pH}$ and consequently cause the release of metals into the supernatant. For example, Park et al., (2008) observed that the concentration of $\mathrm{Zn}$ in the supernatant increased by $50 \%$ after ozonation. Meanwhile, Zhang et al., (2009) found that ozonation decreased the partition coefficient of chromium, copper, mercury, and nickel in sludge. The liberation of metals from sludge due to ozonation may necessitate further treatment (e.g., $\mathrm{pH}$ neutralization or membrane filtration) to ensure effluent quality and reusability.

\subsubsection{Effluent toxicity}

The toxicity of biologically treated effluents arises from the accumulation of toxic and refractory compounds and by-products. The ozonation process can oxidize a wide variety of compounds, including those that are usually resistant to biological treatment. Therefore, the use of ozonation as a pre- and post-treatment decreases or eliminates effluent toxicity (Michael-Kordatou et al., 2016; Vaiopoulou et al., 2015). There is also evidence showing that sludge ozonation significantly contributed to effluent toxicity decrease. Jarvik et al., (2011) treated oil-shale industry wastewater using CAS and found that the effluent had a half maximal effective concentration ( $\mathrm{EC}_{50}$, measured using Daphnia magna) of 76.1. On the other hand, the effluent of CAS coupled with ozonation (30-70 $\mathrm{mg} \mathrm{O}_{3} / \mathrm{L}$ - day) had no trace of toxicity.

\subsection{Sludge properties}

\subsubsection{Biomass activity}

Sludge treatment at a dosage of at least $20 \mathrm{mg} \mathrm{O}_{3} / \mathrm{g}$ TSS induces cell lysis, and this is sufficient to decrease microbial activity in the ozonated sludge fraction (Section 2.2). Although the decline in microbial activity is a sign of sludge solubilisation, the continuous return of ozonated sludge have potential to negatively affect the activity of the main bioreactor. Nie et al., (2014) found that the SOUR $(0.19 \mathrm{mg} \mathrm{O} / \mathrm{g}$ MLSS $\cdot \mathrm{min})$ of CAS ozonated at $100 \mathrm{mg} \mathrm{O}_{3} / \mathrm{g}$ SS was lower than that $(0.23 \mathrm{mg} \mathrm{mg} \mathrm{O} / \mathrm{g}$ MLSS $\cdot \mathrm{min})$ of a non-ozonated CAS. The decrease in SOUR of the main bioreactor implies toxic effects on the biomass or inhibition of metabolic activity, which could negatively impact wastewater treatment efficiency. Operation conditions such as ozone dosage 
and reaction time must be adjusted to avoid system failure (Caravelli et al., 2006; Nie et al., 2014). Previous studies have indicated that an intermediate ozone dosage (30-50 $\mathrm{mg} \mathrm{O}_{3} / \mathrm{g}$ TSS) sustains sludge reduction (Section 2.1) without sacrificing system performance in terms of COD removal efficiency (Section 4.1). Meanwhile, the batch experiments of Albuquerque et al., (2008) showed that sludge ozonated for a short period (5 min) at $12-50 \mathrm{mg} \mathrm{O}_{2} / \mathrm{L}$ eventually recovers its SOUR, whereas sludge ozonated for a long period (10-15 $\mathrm{min}$ ) has permanent SOUR reduction. Nonetheless, the subsequent continuous experiments performed by Albuquerque et al., (2008) demonstrated that a long ozonation period (15 $\mathrm{min})$ is required to obtain $39 \%$ reduction of the sludge yield of CAS. The long term effect of ozonation on the SOUR of CAS was not evaluated (Albuquerque et al., 2008), but the study clearly showed that laboratory or pilot-scale testing is necessary to attain meaningful sludge reduction without decreasing wastewater treatment efficiency.

\subsubsection{Settleability}

The settleability of sludge is crucial in CAS because it determines the separation of supernatant from biomass, and therefore it is directly responsible for the concentration of residual solids in the secondary effluent. Bulking or failure of sludge to settle in sedimentation tanks occurs due to the proliferation (1-20\% volume fraction) of filamentous bacteria in the bioreactor (Martins et al., 2004). The growth of filamentous bacteria is affected by ammonia concentration, dissolved oxygen (DO) concentration, temperature, and other environmental factors. Filamentous bacteria possess a long thread-like morphology with large surface area, and thus settle more slowly than normal floc

-forming bacteria (Rossetti et al., 2005). These microorganisms have also been associated with foaming or the excessive formation of gas bubbles on the surface of bioreactors or clarifiers (Gardoni et al., 2011). Bulking can be controlled through the addition of oxidizing agents, such as chlorine and ozone, that destroy filamentous bacteria (Caravelli et al., 2006). Filamentous bacteria are readily oxidized due to the fact that they grow outside flocs, and are therefore susceptible to oxidizing agents (Martins et al., 2004). Long-term ozonation of RAS has been found to eliminate filamentous bacteria such as Nocardioforms and Microthrix Parvicella (Gardoni et al., 2011). Available reports also confirm 40-70\% decrease in the sludge volume index (SVI) of various reactors (Table 5), which denotes improvement in sludge settleability 
(Demir \& Filibeli, 2012; Gardoni et al., 2011; Meng et al., 2013; Nagare et al., 2008; Paul \& Debellefontaine, 2007). Microscopic observation reveals that ozonation increases the compactness of sludge flocs (Nagare et al., 2008; Paul \& Debellefontaine, 2007). The overall improvement in sludge settleability led to a decrease in the turbidity of effluent (Demir \& Filibeli, 2012) and to an increase in sludge concentration in the aeration tank (e.g., from 4.4 to $5.5 \mathrm{~g} \mathrm{SS} / \mathrm{L})$ (Gardoni et al., 2011). Nonetheless, Demir and Felibeli (2012) found that applying relatively high ozone dosage (e.g., more than $30 \mathrm{mg} \mathrm{O}_{3} / \mathrm{g} \mathrm{TS}$ ) could deteriorate sludge settleability. This was possibly because excessive sludge solubilisation resulted in the formation of fine particles that have poor settling properties.

[Table 5]

\subsubsection{Dewaterability}

Sludge dewatering is a downstream process used to decrease the moisture content and volume of sludge. Removing water from sludge is necessary to minimize the cost of sludge handling and transportation, to facilitate other sludge downstream processes (e.g., incineration), and to meet standards for the land application of biosolids. The process is constrained by colloidal particles and EPS, which have high affinity towards water molecules (Mowla et al., 2013; Park et al., 2008; Tchobanoglus et al., 2003). Therefore, conditioning chemicals such as metal salts and polyelectrolytes are commonly added to facilitate flocculation and enhance sludge watering efficiency (Mowla et al., 2013). Ozonation could either improve or deteriorate dewatering properties depending on ozone dosage. Literature shows that high ozone dosage (e.g., $400 \mathrm{mg}$ $\mathrm{O}_{3} / \mathrm{g}$ solids) is required to improve sludge dewaterability (Kwon et al., 2001; Park et al., 2003). For instance, Park et al., (2003) observed that ozonation at $500 \mathrm{mg} \mathrm{O} / \mathrm{g}$ SS increased the solids concentration of the cake produced by belt filter press from 14 to 20-35\%. Similarly, Kwon et al., (2001) reported that ozonation at $400 \mathrm{mg} \mathrm{O}_{3} / \mathrm{g}$ SS decreased dewatered cake volume by $55 \%$. The increase in dewatering efficiency is attributed to the release of bound water during sludge solubilisation. Park et al., (2003) observed that the bound water content of sludge decreased by $50 \%$ when ozone was increased from 100 to $500 \mathrm{mg} / \mathrm{g} \mathrm{SS}$, and then remained constant when it was further increased. It has also been hypothesized that the destruction organic materials on the floc surface helped facilitate flocculation through surface charge neutralization 
(Kwon et al., 2001; Park et al., 2003). However, ozonation at low dosages ( $<400 \mathrm{mg} \mathrm{O} / \mathrm{g}$ solids) compromised sludge dewaterability (Kwon et al., 2001; Park et al., 2003). The decrease in sludge dewaterability was denoted by an increase in specific resistance to filtration (SRF), which is the measurement of filtration rate at constant pressure difference (Kwon et al., 2001; Park et al., 2003). Similarly, Bougrier et al., (2006) found that ozonation at 100-160 $\mathrm{mg} \mathrm{O}_{3} / \mathrm{g}$ TS decreased sludge dewaterability as evidenced by an increase in capillary suction time (CST) of sludge from 151 to $382 \mathrm{~s}$. CST is the time it takes for water to travel a given distance via capillary action, and is associated with sludge filterability. The deterioration of dewatering properties was potentially due to the increase in the amount of smaller particles, which entails an increase in the surface area available for contact with bound water (Bougrier et al., 2006).

It is important to emphasize that the ozone dosage that deteriorates sludge dewaterability (e.g., less than $400 \mathrm{mg} \mathrm{O}_{3} / \mathrm{g} \mathrm{SS}$ ) (Bougrier et al., 2006; Kwon et al., 2001; Park et al., 2003) is comparable to that typically applied in RAS to achieve sludge reduction (e.g., $30-50 \mathrm{mg} \mathrm{O}_{3} / \mathrm{g}$ TS, Section 3.1). This implies that ozonation of RAS has the potential to worsen sludge dewaterability. There is limited data on the dewaterability of residual sludge of ozonated continuous reactors, but there is some evidence that ozonation affects the EPS characteristics of sludge. Dytczak and Oleszkiewicz (2008) found that the EPS concentration of ozonated SBR was approximately $20 \%$ greater than that of a control SBR. Moreover, the ozonated SBR had greater proportion of floc-bound biopolymers than that of the control. The increase in EPS concentration due to ozonation could have implications on the bound water content and filterability of sludge.

\subsection{Trace organic contaminants}

TrOCs refer to a wide range of compounds found in the environment at very low concentrations (ng to a few $\mu$ g per $\mathrm{L}$ or $\mathrm{kg}$ ). TrOCs have gained much attention due to their resistance to biodegradation, accumulation in tissues, and toxic effects. Some TrOCs interfere with the endocrine system and adversely affect the growth and reproduction of organisms. Traditionally, TrOCs included pesticides, surfactants, plasticizers, and other industrial chemicals. Restriction on compounds such as di(2-ethylhexyl) phthalate (DEHP), linear alkylbenzene sulphonates (LASs), and polycyclic aromatic hydrocarbons (PAHs) are enforced in some countries. In the 
recent years, the potential environmental impacts of trace pharmaceuticals, musks, hormones,

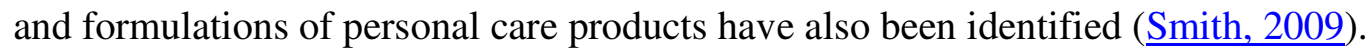

A large fraction of TrOCs in wastewaters could pass through the activated sludge treatment process. The fate of TrOCs depends on their chemical properties (e.g., hydrophobicity and chemical structure) and on WWTP configuration and operation conditions (e.g., sludge retention time). Non-biodegradable and hydrophilic contaminants tend to remain in the aqueous phase and persist in the effluent. Meanwhile, highly hydrophobic contaminants may partition in the solid phase of sludge and accumulate in biosolids. Either pathway potentially results in the dissemination of TrOCs in water bodies and agricultural products (Semblante et al., 2015b).

Ozonation has been utilised to eliminate TrOCs from water, wastewater, and other liquid waste streams (e.g., reverse osmosis or RO concentrate) (Fujioka et al., 2014; $\underline{\text { Huber et al., 2003; Lin et }}$ al., 2014; Nakada et al., 2007; Snyder et al., 2006). Ozonation may result in up to99\% TrOC removal efficiency depending on the type of contaminant and ozonation conditions (Table 6). Furthermore, ozonation may also decrease the overall estrogenic activity of treated effluents (Esplugas et al., 2007). Many contaminants are easily oxidized, but some (e.g., certain synthetic musks and flame retardants) are recalcitrant to ozonation because their chemical structure prohibits ozone attack (Li et al., 2016; Nakada et al., 2007; Snyder et al., 2006). According to Snyder et al., (2006), highly removable contaminants such as carbamazepine, sulfamethoxazole, and trimethoprim can be used as indicators of ozonation performance. In other words, residues of these contaminants will exist only when there is inefficient ozonation arising from low ozone dosage, malfunctioning equipment, or other reasons for ozonation failure.

The ozonation of sludge results in the oxidation of TrOCs (Muz et al., 2013; Qiang et al., 2013), although the oxidation rates in sludge (Table 6) tend to be slower than those in pure water (Qiang et al., 2013). This is attributed to the reaction of ozone and radicals with dissolved compounds in sludge (Chu et al., 2009b; Song et al., 2003) and to the sorption of TrOCs on sludge flocs (Qiang et al., 2013). The likelihood of TrOC oxidation during ozonation is determined by its sorption capacity, which is governed by the chemical structure of the contaminant and the characteristics of sludge (e.g. surface charge, organic fraction, and $\mathrm{pH}$ ) (Semblante et al., 2015b). Generally, TrOCs with octanol-water partitioning coefficient (log D) values greater than three (3) bind with organic particles in sludge (Hai et al., 2014). TrOC 
sorption results in the inefficient mass transfer of aqueous ozone on the bound contaminants, and therefore in poor oxidation efficiency (Huber et al., 2005). This is apparent in the study of Qiang et al. (2013), which reported that the removal of TrOCs with high initial sorption on sludge (e.g., bisphenol A and nonylphenol) was less than those with low sorption capacity (e.g., estrone, estriol, and 17 $\alpha$-ethinylestradiol) under similar ozonation conditions (Table 6). Likewise, the study of Huber et al., (2005) reported that certain TrOCs (e.g., sulfamethoxazole, diclofenac, and naproxen) that do not sorb on effluent suspended solids (TSS=20 mg/L) had high removals (greater than $90 \%$ ).

The pre-treatment of sludge via ozonation or other AOPs has been found to increase TrOC biodegradation in subsequent biological treatment processes such as aerobic or anaerobic digestion (Bernal-Martinez et al., 2007; Muz et al., 2013). This is because sludge solubilisation causes the destruction of sorption sites and the eventual desorption of hydrophobic TrOCs. The liberation of TrOCs from sludge flocs increases their availability for biodegradation (BernalMartinez et al., 2007; Semblante et al., 2015b). This mechanism may occur when ozonated RAS was returned to the main bioreactor. However, only a few studies have reported the fate of TrOCs in such systems, and data have focused on TrOC concentrations in the effluent. Tsuno et al., (2008) reported low concentrations of TrOCs in the effluent of a pilot-scale CAS-ozonation system, but did not elaborate on the effect of sludge ozonation on TrOC removal in the bioreactor. Meanwhile, Nie et al., (2014) observed that laboratory-scale CAS and CASozonation systems had similar effluent TrOC concentrations. This may suggest that the supplementary ozonation module had minimal impact on overall TrOC removal of CAS. Further investigation on the fate of TrOCs in sludge reduction systems will elucidate the impact of ozonation on TrOC biodegradation.

\section{Resource recovery and reuse}

Resource recovery from wastewater and sludge is an appealing approach to wastewater management because it results in the recycling of energy and the formation of value added products (e.g., fertilizers) that can yield revenue for WWTPs. However, recovery rates are usually limited by the low concentration or extractability of the target compounds. To facilitate recovery, a pre-concentration step that accumulates the target compounds in a concentrated 
solution is required. Ozonated sludge supernatant, has elevated concentrations of COD (Section 4.1.1), nitrogen (Section 4.1.2), and phosphorous (Section 4.1.3), and is a potential source where they could be retrieved. Thus far, the continuous recovery of phosphorous from ozonated sludge supernatant has been successfully achieved in several studies (Kondo et al., 2009; Qiang et al., 2015; Tsuno et al., 2008). There is also potential for other resources such as COD to be recovered or reused with the help of ozonation technology.

\subsection{COD recovery}

Large amounts of COD may be solubilized due to ozonation depending on the dosage (Table 3). A significant portion of the solubilized COD is biodegradable, and therefore could be re-used as a substrate in other biological processes (Romero et al., 2015). One such process is denitrification, which is potentially inhibited by a shortage of substrate due to its consumption in the preceding nitrifying stage. Park et al., (2004) used the supernatant of ozonated sludge as a supplementary carbon source for denitrification in batch reactions. The denitrification rate obtained using the supernatant of ozonated sludge (3.66 mg N/g VSS) was comparable to denitrification rates achieved using pure compounds (e.g., acetate and methanol). Furthermore, by recirculating ozonated sludge, the total nitrogen removal of a pilot-scale process with intermittent decanting and extended aeration was enhanced (Park et al., 2004). Similarly, other studies found that the filtrate of ozonated sludge had similar denitrification potential as wastewater ( Romero et al., 2015) or glucose (Ahn et al., 2002). Additionally, there appears to be a correlation between ozone dosage and denitrification potential of ozonated sludge supernatant. Using batch experiments, Romero et al. (2015) showed that increasing ozone dosage (0.76-2.0 $\mathrm{mg} \mathrm{O} / \mathrm{g}$ MLVSS) enhanced denitrification rate of a mixed liquor fed with the filtrate of ozonated sludge from 5 to $22 \mathrm{~g} \mathrm{NO}_{\mathrm{x}}-\mathrm{N} / \mathrm{kg}$ MLVSS/d. Similarly, Dytzak et al., (2007) reported that the nitrate uptake rate of an anoxic tank fed with ozonated sludge-supernatant directly increased with ozone dosage (0.02-0.06 $\mathrm{mg} \mathrm{O}_{3} / \mathrm{g}$ TSS). Nonetheless, there are also instances wherein recirculation of ozonated sludge failed to enhance nitrogen removal (Gardoni et al., 2011; Meng et al., 2013; Naso et al., 2008). This was possibly because of excessive nitrogen release in the nitrification step or insufficient COD/N ratio (Park et al., 2004). In such cases, nitrogen removal may improve if the amount of ozonated sludge (Romero et al., 2015) or ozone dosage (Dytczak et al., 2007) were manipulated so that sufficient soluble COD is generated and supplied to the denitrification reactor. 


\subsection{Phosphorous recovery}

Phosphorus is a vital nutrient in plant growth that cannot be substituted by other elements (Tchobanoglus et al., 2003). Phosphorous recovery from waste streams is attractive because the global supply of natural phosphate deposits is gradually diminishing and demand for phosphorus-based fertilizers in agriculture is constantly increasing. Phosphorous solubilized by ozonation can be recovered by crystallization or adsorption. Phosphorous crystallization typically involves the formation of magnesium ammonium phosphate (MAP, commonly called struvite) or calcium phosphate (commonly called hydroxyapatite or HAP) (Cornel \& Schaum, 2009). The group of Saktaywin et al. (2006; 2005) first reported the crystallization of phosphorous in an ozonated sludge system. In their study, a laboratory-scale aerobic/anoxic reactor was integrated with specialized units for sludge ozonation, phosphorous release, and phosphorous crystallization. PAOs consumed the substrates released by ozonation in the aerobic phase. These PAOs emitted orthophosphate to the sludge supernatant in the anaerobic phosphorous release unit. Approximately $70 \%$ of released orthophosphate was recovered in the crystallization unit without chemical addition (Saktaywin et al., 2006). Tsuno et al. (2008) ran a pilot-scale anaerobic/anoxic/aerobic reactor integrated with ozonation and crystallization units and fed with real wastewater. The system achieved $75 \%$ phosphorous recovery and maintained effluent total phosphorous (TP) concentration of less than $1 \mathrm{mg} / \mathrm{L}$ (Tsuno et al., 2008). Recently, Qiang et al., (2015) operated a pilot scale anaerobic/anoxic/aerobic reactor with ozonation and

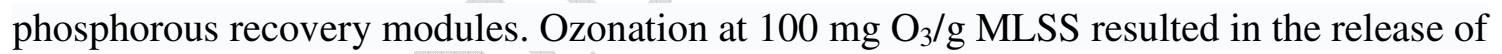
approximately $44 \mathrm{mg} \mathrm{PO}_{4}{ }^{3-}-\mathrm{P} / \mathrm{L}$. Calcium hydroxide was added to the supernatant to adjust $\mathrm{Ca} / \mathrm{P}$ molar ratio to 10 and recover $29 \%$ of influent phosphorous. It is worth mentioning that in addition to recovering phosphorous, the aforementioned studies achieved $60-85 \%$ sludge reduction (Qiang et al., 2015; Saktaywin et al., 2006; Tsuno et al., 2008).

Adorption is another approach to recover phosphorous from solubilized sludge. Suzuki et al., (2006) operated a laboratory-scale anaerobic/aerobic/anoxic reactor integrated with an ozonation tank and a phosphorus adsorption column packed with zirconium ferrite. The process removed $85 \%$ of influent phosphorous and recovered $80 \%$ of solubilized phosphorous through the adsorption column, but had a slight deterioration of total organic carbon (TOC) removal due to sludge solubilisation. Kondo et al., (2009) reported that a zirconium ferrite column recovered $90 \%$ of phosphorous solubilized by ozonation. Phosphorous recovery decreased when the 
adsorbent reached its maximum adsorption capacity, but the column was easily reactivated using acid solution and regained its previous performance. Available literature suggests that adsorption (80-90\%) (Kondo et al., 2009; Suzuki et al., 2006) achieves a higher recovery of solubilized phosphorous than crystallization (30-75\%) (Qiang et al., 2015; Tsuno et al., 2008). Furthermore, adsorption is potentially a more cost-effective approach than crystallization because adsorption columns can be reactivated and reused (Kondo et al., 2009).

Overall, coupling sludge ozonation and phosphorous recovery appears to have synergistic effect on system performance. If not recovered, phosphorous released from sludge by ozonation may decrease effluent quality (Section 4.1.3). Studies have shown that with the addition of phosphorous recovery units, the risk of phosphorous accumulation in the reactor is prevented (Kondo et al., 2009; Suzuki et al., 2006). This suggests that phosphorous recovery must always be performed if sludge reduction in EBPRs is desired.

There are novel technologies (e.g., microbial fuel cells, supercritical water oxidation, and membrane filtration) that have potential to recover phosphorous from ozonated sludge. For example, microbial fuel cells (MFCs) recovered $80 \%$ of phosphorous from landfill leachate (Iskander et al., 2016). MFC has an anaerobic chamber, which contains an anodic electrode that receives electrons produced by anaerobic biodegradation of organic matter. A salt bridge or membrane separates the anaerobic chamber from the aerobic chamber, which contains a cathodic electrode that receives the flow of electrons from the anode. Phosphorous was precipitated as MAP in the high pH zone of the anaerobic chamber (Iskander et al., 2016). Supercritical water oxidation (SCWO) involves treatments performed at temperature and pressure that are higher than a certain mixture's thermodynamic critical point (i.e., the endpoint of a phase equilibrium curve) (Stendahl \& Jäfverström, 2004). SCWO treatment of anaerobically digested sludge produced inorganic ash residue (0.44 tonne DS/tonne DS sludge). By sulphuric acid addition, 0.18 tonne of ferric phosphate $\left(\mathrm{FePO}_{4}\right)$ as DS was recovered from ash. Ferric phosphate can be applied on land directly as replacement for common artificial fertilizers (Johansson et al., 2008). Forward osmosis (FO) involves a semi-permeable membrane that can separate water from solutes (Xie et al., 2014). FO is driven by the osmotic pressure gradient between feed (low solute concentration) and draw (high solute concentration) solutions. FO was used to pre-concentrate orthophosphate and ammonium from anaerobically digested sludge centrate, and MAP (Xie et 
al., 2014) or HAP (Ansari et al., 2016) was subsequently precipitated from the concentrated solution. The aforementioned processes were useful for pre-concentrating orthophosphate and/or facilitating phosphorous precipitation. They can be used in tandem with ozonation to further enhance the recovery of phosphorous or other valuable products (e.g., MFC produces electrical energy).

\subsection{Recovery of other resources}


Other valuable compounds, such as nitrogen (Section 4.1.2) and metals (Section 4.1.4), are liberated from sludge by ozonation. Ammonia is precipitated along with phosphorous through the formation of MAP (Section 5.2). Beyond this, no other strategy to recover nitrogen from ozonated sludge has been reported. Likewise, the recovery of metals from ozonated sludge has not been explored. Nonetheless, biological or chemical approaches have been utilized to recover the aforementioned compounds from various waste streams. For instance, microbial electrolysis cell (MEC) was used to recover 60-80\% of ammonium from landfill leachate (Qin et al., 2016) and wastewater (Zhang et al., 2014). A basic MEC has cathode and anode separated by an ionexchange membrane. Electrochemically active microorganisms in the anodic chamber consume substrate and produce electrons, protons, and carbon dioxide. Voltage $(\geq 0.2 \mathrm{~V})$ is supplied to the cell to facilitate the flow of electrons to the cathode, wherein they combine with protons to produce hydrogen gas that can be used as energy source (Kadier et al., 2016). Ammonium is enriched in the cathodic chamber, and can be separated using membrane filtration (e.g., FO) (Qin et al., 2016) or precipitation. Additionally, ammonia recovered can be consumed by photosynthetic bacteria or algae for growth (Matassa et al., 2015). The biomass is a direct source of protein, fertilizer, or animal feed (Matassa et al., 2015). Meanwhile, various strong and weak acids were used to leach $\mathrm{Pb}, \mathrm{Zn}, \mathrm{Cu}, \mathrm{Cd}, \mathrm{Cr}$, and $\mathrm{Ni}$ from thermally liquefied dewatered sludge (Yuan et al., 2011). Weak bases such as thiourea $\left(\mathrm{CH}_{4} \mathrm{~N}_{2} \mathrm{~S}\right)$ and thiosulfate $\left(\mathrm{S}_{2} \mathrm{O}_{3}{ }^{2-}\right)$ were used to convert insoluble metals such $\mathrm{Au}$ and $\mathrm{Ag}$ from ores into soluble complexes, but this approach has not been tested on sludge (Mulchandani \& Westerhoff, 2016). Furthermore, well-known pyrometallurgical, hydrometallurgical, electrochemical techniques have been used for extracting metals from industrial wastewater (Cui \& Zhang, 2008; Wang \& Ren, 2014). These methods may be used in tandem with ozonation to retrieve valuable materials from sludge, which will facilitate resource and energy recycling within the wastewater treatment loop.

\section{Economic considerations}

The primary drawback of ozonation is the high cost of infrastructure, equipment maintenance, and operation. The cost of ozonation depends on operation conditions (ozone dosage, amount of treated sludge, and others). Some studies have performed a thorough economic evaluation of sludge ozonation in terms of electricity consumption. Huysmans et al., (2001) reported that the cost of ozone installation and production was 3.75 EUR or 4.20 USD per $\mathrm{kg}$ of $\mathrm{O}_{3}$ produced (1 
EUR=1.12 USD as of 2016). The total cost of sludge ozonation with no excess sludge production was comparable to that of normal CAS operation. Sludge ozonation costed 538 USD/tonne DS for ozone production and $56 \mathrm{USD} /$ tonne DS for additional aeration in the SBR to treat the soluble COD of ozonated sludge, which results in a total cost of 594 USD/tonne DS. The same amount was expended in CAS for excess sludge dewatering (202 USD/tonne DS), transport (56 USD/tonne DS, and incineration (280 USD/tonne DS) (Huysmans et al., 2001). However, in that scenario, it can be inferred that ozonation could result additional savings by eliminating landfill levies for residual ash. Romero et al., (2015) reported that the operation of a full-scale ozonation unit for a medium-sized WWTP $\left(10,400 \mathrm{~m}^{3} / \mathrm{d}\right)$ took up $14 \%$ of the total power consumption of the plant. The cost of ozonation reported by Romero et al., (2015) (0.05 EUR or 0.06 USD per $\mathrm{kg}$ of $\mathrm{O}_{3} ; 1 \mathrm{EUR}=1.12$ USD as of 2016) was significantly lower than the estimation of Huysmans et al., (2001) probably due to variation in technical aspects such as ozone concentration and generator design. With annual generation of $3,276 \mathrm{~kg} \mathrm{O}_{3}$, which was consumed to reduce sludge by $10 \%$, the total cost of the ozonation system was 6,605 USD/year (Romero et al., 2015). Using the life-cycle inventory of sludge treatment and disposal reported by Murray et al., (2008), it can be inferred that the annual ozonation cost in the study of Romero et al., (2015) could be easily offset by savings in sludge dewatering alone. Further savings can be attained through reductions in sludge drying, digestion, transportation, and other downstream processes. The costs associated with ozonation could be minimized if optimum conditions were implemented. For instance, Chiavola et al., (2013) reported that increasing ozone dosage applied to an aerobic digester from 1.23 to $1.40 \mathrm{~g} \mathrm{O}_{3} / \mathrm{kg}$ TSS caused nominal decrease in the amount of sludge disposed, but increased the operating cost of the system. Therefore, low ozone dosage was preferentially implemented to compensate the cost of sludge disposal.

Literature shows that the true cost of ozonation is augmented by energy spent to ensure effluent quality (e.g., additional aeration in CAS to remove surplus COD in ozonated sludge) (Huysmans et al., 2001). Bearing this in mind, an assessment of the potential cost of phosphorous removal due to the release of phosphorous and/or inactivation of EBPR (Section 4.1.3) must be performed. Despite the additional expenditure, studies demonstrated that ozonation is economically acceptable because it decreases the costs associated with downstream processes (e.g., dewatering and incineration) as the excess sludge wastage is reduced (Chiavola et al., 2013; Huysmans et al., 2001; Romero et al., 2015; Tsuno et al., 2008). Capitalizing on ozonation 
to recover resources from sludge (e.g., COD, ammonium, and phosphorous; Section 5) could further offset operation costs. An economic evaluation of ozone-assisted resource recovery must be performed to shed light on the potential savings and/or revenue of this approach. The capacity of ozonation to remove TrOCs in the effluent and to enhance the quality of biosolids provides additional economic incentives for the application of this technology in sludge management.

\section{Recommendations}

\subsection{Challenges in full-scale implementations}

Due to the extensive research effort, full-scale sludge ozonation has been successfully deployed in some countries (Paul et al., 2012). Commercial ozonation packages especially designed for sludge reduction, such as Aspal Sludge ${ }^{\mathrm{TM}}$ (Air Liquide, UK) and Lyso ${ }^{\mathrm{TM}}$ (Praxair, USA) (Chiavola et al., 2013), are also available in the market. Although significant progress has been achieved over the years, challenges associated with operation and mechanistic processes persist in full-scale implementations. One issue is the potential increase of nutrient concentration in the effluent. Gardoni et al., (2011) showed that the installation of sludge ozonation in a full-scale anoxic/aerobic system caused the nitrogen removal efficiency to decrease from 58 to $48 \%$. The decline was caused by high oxygen load from the ozonated sludge fraction, which inhibited facultative denitrifying bacteria (Section 4.1.1). Simultaneously, phosphorous removal decreased from 70 to $28 \%$ probably because the biomass that used to take up orthophosphate was reduced (Gardoni et al., 2011) (Section 4.1.3). A deterioration in nitrogen removal was likewise observed in a full-scale anaerobic/anoxic/aerobic system (Meng et al., 2013), which caused nitrate accumulation in the aerobic phase and increased the effluent TN concentration $(<20 \mathrm{mg} / \mathrm{L})$ to levels greater than the Chinese Level 1 Class A discharge standards. The increase in TN was probably due to high inorganic nitrogen load of ozonated sludge, which inhibited denitrification. Meanwhile, the deterioration in phosphorous removal was similarly observed in laboratory- (Nie et al., 2014) and pilot-scale (Qiang et al., 2015) studies due to the decrease in sludge withdrawal and release of orthophosphate from solubilized sludge (Section 4.1.3). To resolve these issues, additional treatment steps (e.g., chemical precipitation) can be incorporated to increase effluent quality (Tchobanoglus et al., 2003). Alternatively, the nutrients in the effluent can be recovered by physico-chemical means (Section 5). The recovery of nutrients is an appealing approach because not only does it help maintain effluent quality, it also leads to the production of value 
added products. Therefore, the adaptation of nutrient recovery methods in full-scale sludge ozonation systems is likely the next major step to the development of this technology.

Understanding the effect of ozonation on microbial diversity of sludge in full-scale plants is a knowledge gap that has potential to yield useful insight on mechanistic process of sludge reduction. Data acquired from other systems reveal that microbial diversity is intrinsically related to process performance such as sludge reduction (Ning et al., 2014), methanogenic activity (Cho et al., 2016) , and TrOC removal (Phan et al., 2016), among others. The unique effect of ozonation on the survival of specific bacterial groups, e.g., nitrifying bacteria and PAOs (Saktaywin et al., 2005), is well-known. Therefore, there is a strong likelihood that the continuous ozonation of sludge could shift microbial community structure (Section 2.3). However, thus far, there are limited and inconclusive reports on this topic. For instance, PCRDGGE analysis of laboratory-scale ozonated sludge showed that ozonation enhanced microbial diversity (Yan et al., 2009), but T-RLFP analysis of full-scale ozonated anaerobic digesters suggested that ozonation had no impact on both microbial diversity and sludge reduction (Chiellini et al., 2014) (Section 2.3). The use of more sensitive DNA analysis (e.g., 454 pyrosequencing) (Ning et al., 2014; Phan et al., 2016) can be considered to elucidate the relationship of ozonation and sludge reduction.

\subsection{Future research}

The most relevant factor affecting sludge reduction is ozone dosage. However, until now, there is a lack of undersanding about how ozone is adsorbed by sludge particles and the impact of this on sludge solubilisation. Consequently, studies heavily rely on the empirical determination of the optimum ozone dosage and there is minimal understanding of the mass transfer of ozone to the sludge matrix. It is worthwhile to consider the mechanism of ozone adsorption on sludge and the underlying biological mechanism/s in sludge reduction (Section 7.1), and how these will affect the selection of ozone dosage, contact time, and other conditions relevant to the operation of the ozone reactor. Additionally, although studies have shown that ozonation improves sludge quality parameters such as settleability (Section 4.2.2), there is evidence that it can deteriorate dewaterability especially at dosages frequently used for sludge reduction (Section 4.2.3). Any decline in sludge dewaterability represents an additional technical challenge and cost for 
conditioning chemicals and/or sludge handling. Therefore, further examination of the impact of ozonation on sludge dewatering properties such as CST and SRF must be performed (Section 4.2.3). Finally, future research must focus on incorporating the recovery of resources from the ozonated sludge supernatant, which is potentially rich in soluble materials such as COD, nutrients, and metals (Section 5). Several research groups have already pioneered the use of precipitation and adsorption (Section 5.2) to retrieve phosphorous from ozonated sludge. The use of other technologies (e.g., membrane filtration and bioelectrical systems) in tandem with ozonation must be explored to facilitate or improve resource recovery from sludge.

\section{Conclusion}

This review showed that ozone dosage is the foremost factor affecting sludge reduction efficiency. However, other factors such as the operational parameters of the ozonation reactor and the characteristics of sludge could have significant impact as well. Ozonation of RAS can result in a considerable reduction of excess sludge (up to 100\%), removal of trace organic contaminants from the effluent, and improvement in sludge settleability. Effluent quality may deteriorate due to release of COD and nutrients during sludge ozonation. However, the application of resource recovery facilities (e.g., coagulation or adsorption) could be considered to minimise the impact of ozonation on effluent quality and offset the costs associated with equipment and maintenance. Future research must focus on the impact of ozonation on downstream sludge processes (e.g., dewatering) and on the integration of resource recovery in sludge reduction systems.

\section{Acknowledgements}

We would like to thank the University of Wollongong for the $\mathrm{PhD}$ scholarship of Galilee Semblante.

\section{References}

Ahn, K.H., Park, K.Y., Maeng, S.K., Hwang, J.H., Lee, J.W., Song, K.G., Choi, S. 2002. Ozonation of wastewater sludge for reductio and recycling. in: Water Sci Technol, Vol. 46, pp. 71-77.

Albuquerque, J.S., Domingos, J.C., Sant'Anna Jr, G.L., Dezotti, M. 2008. Application of ozonation to reduce biological sludge production in an industrial wastewater treatment plant. in: Water Sci Technol, Vol. 58, pp. 1971-1976. 
Ansari, A.J., Hai, F.I., Price, W.E., Nghiem, L.D. 2016. Phosphorus recovery from digested sludge centrate using seawater-driven forward osmosis. Sep Purif Technol, 163, 1-7.

Arakawa, K., Suyama, T., Tanaka, T. 2011. Verification of Sludge Reduction by Ozonation with Phosphorus Recovery Process at a Demonstration Plant. Ozone Sci Eng, 33, 171-178.

Bernal-Martinez, A., Carrère, H., Patureau, D., Delgenès, J.P. 2007. Ozone pre-treatment as improver of PAH removal during anaerobic digestion of urban sludge. Chemosphere, 68, 1013-1019.

Böhler, M., Siegrist, H. 2004. Partial ozonation of activated sludge to reduce excess sludge, improve denitrification and control scumming and bulking. in: Water Sci Technol, Vol. 49, pp. 41-49.

Bougrier, C., Albasi, C., Delgenès, J.P., Carrère, H. 2006. Effect of ultrasonic, thermal and ozone pre-treatments on waste activated sludge solubilisation and anaerobic biodegradability. Chem Eng Process, 45, 711-718.

Caravelli, A., Giannuzzi, L., Zaritzky, N. 2006. Effect of Ozone on Filamentous Bulking in a Laboratory Scale Activated Sludge Reactor Using Respirometry and INT-Dehydrogenase Activity. J Environ Eng, 132, 1001-1010.

Chiavola, A., D'Amato, E., Gori, R., Lubello, C., Sirini, P. 2013. Techno-economic evaluation of the application of ozone-oxidation in a full-scale aerobic digestion plant. Chemosphere, 91, 656-662.

Chiellini, C., Gori, R., Tiezzi, A., Brusetti, L., Pucciarelli, S., D'Amato, E., Chiavola, A., Sirini, P., Lubello, C., Petroni, G. 2014. Ozonation effects for excess sludge reduction on bacterial communities composition in a full-scale activated sludge plant for domestic wastewater treatment. Environ Technol, 35, 1462-1469.

Cho, S.-K., Kim, D.-H., Quince, C., Im, W.-T., Oh, S.-E., Shin, S.G. 2016. Low-strength ultrasonication positively affects methanogenic granules toward higher AD performance: Implications from microbial community shift. Ultrason Sonochem, 32, 198-203.

Chu, L., Wang, J., Wang, B., Xing, X.-H., Yan, S., Sun, X., Jurcik, B. 2009a. Changes in biomass activity and characteristics of activated sludge exposed to low ozone dose. Chemosphere, 77, 269-272.

Chu, L., Yan, S., Xing, X.-H., Sun, X., Jurcik, B. 2009b. Progress and perspectives of sludge ozonation as a powerful pretreatment method for minimization of excess sludge production. Water Res, 43, 1811-1822.

Clarke, R.M., Cummins, E. 2015. Evaluation of "Classic" and Emerging Contaminants Resulting from the Application of Biosolids to Agricultural Lands: A Review. Hum Ecol Risk Assess, 21, 492-513.

Cornel, P., Schaum, C. 2009. Phosphorus recovery from wastewater: Needs, technologies and costs. Water Sci Technol, 59, 1069-1076.

Cui, J., Zhang, L. 2008. Metallurgical recovery of metals from electronic waste: A review. $J$ Hazard Mater, 158, 228-256.

Deleris, S., Geaugey, V., Camacho, P., Debellefontaine, H., Paul, E. 2002. Minimization of sludge production in biological processes: An alternative solution for the problem of sludge disposal. in: Water Sci Technol, Vol. 46, pp. 63-70.

Déléris, S., Paul, E., Audic, J.M., Roustan, M., Debellefontaine, H. 2000. Effect of Ozonation on Activated Sludge Solubilization and Mineralization. Ozone Sci Eng, 22, 473-486. 
Demir, O., Filibeli, A. 2014. Effects of partial ozonation on activated sludge process for the minimization of excess sludge production during biological treatment. Desalin Water Treat, 52, 3063-3075.

Demir, O., Filibeli, A. 2012. Fate of return activated sludge after ozonation: an optimization study for sludge disintegration. Environ Technol, 33, 1869-1878.

Dytczak, M.A., Londry, K.L., Siegrist, H., Oleszkiewicz, J.A. 2007. Ozonation reduces sludge production and improves denitrification. Water Res, 41, 543-550.

Dytczak, M.A., Oleszkiewicz, J.A. 2008. Performance change during long-term ozonation aimed at augmenting denitrification and decreasing waste activated sludge. Chemosphere, 73, 1529-1532.

Esplugas, S., Bila, D.M., Krause, L.G.T., Dezotti, M. 2007. Ozonation and advanced oxidation technologies to remove endocrine disrupting chemicals (EDCs) and pharmaceuticals and personal care products (PPCPs) in water effluents. J Hazard Mater, 149, 631-642.

Feng, X.-C., Guo, W.-Q., Yang, S.-S., Zheng, H.-S., Du, J.-S., Wu, Q.-L., Ren, N.-Q. 2014. Possible causes of excess sludge reduction adding metabolic uncoupler, 3,3',4',5tetrachlorosalicylanilide (TCS), in sequence batch reactors. Bioresource Technol, 173, 96-103.

Foladori, P., Andreottola, G., Ziglio, G. 2010. Sludge reduction technologies in wastewater treatment plants. IWA Publishing, London.

Fujioka, T., Khan, S.J., McDonald, J.A., Nghiem, L.D. 2014. Ozonation of N-Nitrosamines in the Reverse Osmosis Concentrate from Water Recycling Applications. Ozone Sci Eng, 36, 174-180.

Fytili, D., Zabaniotou, A. 2008. Utilization of sewage sludge in EU application of old and new methods-A review. Renew Sust Energ Rev, 12, 116-140.

Gardoni, D., Ficara, E., Fornarelli, R., Parolini, M., Canziani, R. 2011. Long-term effects of the ozonation of the sludge recycling stream on excess sludge reduction and biomass activity at full-scale. Water Sci Technol, 63, 2032-2038.

Gardoni, D., Ficara, E., Vergine, P., Canziani, R. 2015. A full-scale plug-flow reactor for biological sludge ozonation. Water Sci Technol, 71, 560-565.

Gerrity, D., Snyder, S. 2011. Review of Ozone for Water Reuse Applications: Toxicity, Regulations, and Trace Organic Contaminant Oxidation. Ozone Sci Eng, 33, 253-266.

Ghyoot, W., Verstraete, W. 2000. Reduced sludge production in a two-stage membrane-assisted bioreactor. Water Res, 34, 205-215.

Goel, R., Takutomi, T., Yasui, H. 2003. Anaerobic digestion of excess activated sludge with ozone pretreatment. in: Water Sci Technol, Vol. 47, pp. 207-214.

Gommers, K., De Wever, H., Brauns, E., Peys, K. 2007. Recalcitrant COD degradation by an integrated system of ozonation and membrane bioreactor. in: Water Sci Technol, Vol. 55, pp. 245-251.

Guo, W.-Q., Yang, S.-S., Xiang, W.-S., Wang, X.-J., Ren, N.-Q. 2013. Minimization of excess sludge production by in-situ activated sludge treatment processes - A comprehensive review. Biotechnol Adv, 31, 1386-1396.

Hai, F.I., Nghiem, L.D., Khan, S.J., Price, W.E., Yamamoto, K. 2014. Wastewater reuse: Removal of Emerging Trace Organic Contaminants by Membrane Bioreactors. in: Membrane biological reactors, (Eds.) F.I. Hai, K. Yamamoto, C.H. Lee, IWA publishing. UK, pp. 165-205. 
Huang, X., Liang, P., Qian, Y. 2007. Excess sludge reduction induced by Tubifex tubifex in a recycled sludge reactor. J Biotechnol, 127, 443-451.

Huber, M.M., Canonica, S., Park, G.-Y., von Gunten, U. 2003. Oxidation of Pharmaceuticals during Ozonation and Advanced Oxidation Processes. Environ Sci Technol, 37, 10161024.

Huber, M.M., GÖbel, A., Joss, A., Hermann, N., LÖffler, D., McArdell, C.S., Ried, A., Siegrist, H., Ternes, T.A., von Gunten, U. 2005. Oxidation of Pharmaceuticals during Ozonation of Municipal Wastewater Effluents: A Pilot Study. Environ Sci Technol, 39, 4290-4299.

Huysmans, A., Weemaes, M., Fonseca, P.A., Verstraete, W. 2001. Ozonation of activated sludge in the recycle stream. J Chem Technol Biotechnol, 76, 321-324.

Isazadeh, S., Feng, M., Urbina Rivas, L.E., Frigon, D. 2014. New mechanistically based model for predicting reduction of biosolids waste by ozonation of return activated sludge. $J$ Hazard Mater, 270, 160-168.

Iskander, S.M., Brazil, B., Novak, J.T., He, Z. 2016. Resource recovery from landfill leachate using bioelectrochemical systems: Opportunities, challenges, and perspectives. Bioresource Technol, 201, 347-354.

Järvik, O., Viiroja, A., Kamenev, S., Kamenev, I. 2011. Activated sludge process coupled with intermittent ozonation for sludge yield reduction and effluent water quality control. $J$ Chem Technol Biotechnol, 86, 978-984.

Johansson, K., Perzon, M., Fröling, M., Mossakowska, A., Svanström, M. 2008. Sewage sludge handling with phosphorus utilization - life cycle assessment of four alternatives. J Clean Prod, 16, 135-151.

Kadier, A., Simayi, Y., Abdeshahian, P., Azman, N.F., Chandrasekhar, K., Kalil, M.S. 2016. A comprehensive review of microbial electrolysis cells (MEC) reactor designs and configurations for sustainable hydrogen gas production. Alex Eng J, 55, 427-443.

Kang, J.-h., Kim, D., Lee, T.-j. 2012. Hydrogen production and microbial diversity in sewage sludge fermentation preceded by heat and alkaline treatment. Bioresource Technol, 109, 239-243.

Khursheed, A., Kazmi, A.A. 2011. Retrospective of ecological approaches to excess sludge reduction. Water Res, 45, 4287-4310.

Komanapalli, I.R., Lau, B.H.S. 1996. Ozone-induced damage of Escherichia coli K-12. Appl Microbiol Biotechnol, 46, 610-614.

Kondo, T., Tsuneda, S., Ebie, Y., Inamori, Y., Xu, K. 2009. Improvement of nutrient removal and phosphorus recovery in the anaerobic/oxic/anoxic process combined with sludge ozonation and phosphorus adsorption. J Water Environ Technol, 7, 135-142.

Kwon, J.H., Ryu, S.H., Park, K.Y., Yeom, I.T., Ahn, K.H. 2001. Enhancement of sludge dewaterability by ozone treatment. J Chin Inst Chem Eng, 32, 555-558.

Labelle, M.A., Ramdani, A., Deleris, S., Gadbois, A., Dold, P., Comeau, Y. 2011. Ozonation of endogenous residue and active biomass from a synthetic activated sludge. Water Sci Technol, 63, 297-302.

Li, C.-S., Wang, Y.-C. 2003. Surface Germicidal Effects of Ozone for Microorganisms. Am Ind Hyg Assoc J, 64, 533-537.

Li, W., Nanaboina, V., Chen, F., Korshin, G.V. 2016. Removal of polycyclic synthetic musks and antineoplastic drugs in ozonated wastewater: Quantitation based on the data of differential spectroscopy. J Hazard Mater, 304, 242-250. 
Lin, A.Y.-C., Hsueh, J.H.-F., Hong, P.K.A. 2014. Removal of antineoplastic drugs cyclophosphamide, ifosfamide, and 5-fluorouracil and a vasodilator drug pentoxifylline from wastewaters by ozonation. Environ Sci Poll Res, 22, 508-515.

Liu, Y. 2003. Chemically reduced excess sludge production in the activated sludge process. Chemosphere, 50, 1-7.

Liu, Y., Fang, H.H.P. 2003. Influences of extracellular polymeric substances (EPS) on flocculation, settling, and dewatering of activated sludge. Crit Rev Environ Sci Technol, 33, 237-273.

Luxmy, B.S., Kubo, T., Yamamoto, K. 2001. Sludge reduction potential of metazoa in membrane bioreactors. in: Water Sci Technol, Vol. 44, pp. 197-202.

Manterola, G., Uriarte, I., Sancho, L. 2008. The effect of operational parameters of the process of sludge ozonation on the solubilisation of organic and nitrogenous compounds. Water Res, 42, 3191-3197.

Martins, A.M.P., Pagilla, K., Heijnen, J.J., van Loosdrecht, M.C.M. 2004. Filamentous bulking sludge-a critical review. Water Res, 38, 793-817.

Matassa, S., Batstone, D.J., Hülsen, T., Schnoor, J., Verstraete, W. 2015. Can Direct Conversion of Used Nitrogen to New Feed and Protein Help Feed the World? Environ Sci Technol, 49, 5247-5254.

Meng, X., Liu, D., Frigon, M. 2015. The process of activated sludge ozonation: Effect of ozone on cells, flocs, macromolecules and nutrient release. Water Sci Technol, 71, 1026-1032.

Meng, X., Liu, D., Yang, K., Song, X., Zhang, G., Yu, J., Zhang, J., Tang, Y., Li, K. 2013. A full scale anaerobic-anoxic-aerobic process coupled with low-dose ozonation for performance improvement. Bioresource Technol, 146, 240-246.

Michael-Kordatou, I., Andreou, R., Iacovou, M., Frontistis, Z., Hapeshi, E., Michael, C., FattaKassinos, D. 2016. On the capacity of ozonation to remove antimicrobial compounds, resistant bacteria and toxicity from urban wastewater effluents. J Hazard Mater.

Mowla, D., Tran, H.N., Allen, D.G. 2013. A review of the properties of biosludge and its relevance to enhanced dewatering processes. Biomass Bioenerg, 58, 365-378.

Mulchandani, A., Westerhoff, P. 2016. Recovery opportunities for metals and energy from sewage sludges. Bioresource Technol, 215, 215-226.

Murray, A., Horvath, A., Nelson, K.L. 2008. Hybrid Life-Cycle Environmental and Cost Inventory of Sewage Sludge Treatment and End-Use Scenarios: A Case Study from China. Environ Sci Technol, 42, 3163-3169.

Muz, M., Ak, M.S., Komesli, O.T., Gökçay, C.F. 2013. An ozone assisted process for treatment of EDC's in biological sludge. Chem Eng J, 217, 273-280.

Nagare, H., Tsuno, H., Saktaywin, W., Soyama, T. 2008. Sludge Ozonation and its Application to a New Advanced Wastewater Treatment Process with Sludge Disintegration. Ozone Sci Eng, 30, 136-144.

Nakada, N., Shinohara, H., Murata, A., Kiri, K., Managaki, S., Sato, N., Takada, H. 2007. Removal of selected pharmaceuticals and personal care products (PPCPs) and endocrinedisrupting chemicals (EDCs) during sand filtration and ozonation at a municipal sewage treatment plant. Water Res, 41, 4373-4382.

Naso, M., Chiavola, A., Rolle, E. 2008. Application of excess activated sludge ozonation in an SBR Plant. Effects on substrate fractioning and solids production. in: Water Sci Technol, Vol. 58, pp. 239-245. 
Nie, Y., Qiang, Z., Ben, W., Liu, J. 2014. Removal of endocrine-disrupting chemicals and conventional pollutants in a continuous-operating activated sludge process integrated with ozonation for excess sludge reduction. Chemosphere, 105, 133-138.

Ning, X., Qiao, W., Zhang, L., Gao, X. 2014. Microbial community in anoxic-oxic-settlinganaerobic sludge reduction process revealed by 454 pyrosequencing analysis. Can J Microbiol, 60, 799-809.

Park, K.Y., Ahn, K.-H., Maeng, S.K., Hwang, J.H., Kwon, J.H. 2003. Feasibility of Sludge Ozonation for Stabilization and Conditioning. Ozone Sci Eng, 25, 73-80.

Park, K.Y., Lee, J.W., Ahn, K.-H., Maeng, S.K., Hwang, J.H., Song, K.-G. 2004. Ozone Disintegration of Excess Biomass and Application to Nitrogen Removal. Water Environ Res, 76, 162-167.

Park, K.Y., Maeng, S.K., Song, K.G., Ahn, K.H. 2008. Ozone treatment of wastewater sludge for reduction and stabilization. J Environ Sci Health A, 43, 1546-1550.

Paul, E., Debellefontaine, H. 2007. Reduction of Excess Sludge Produced by Biological Treatment Processes: Effect of Ozonation on Biomass and on Sludge. Ozone Sci Eng, 29, 415-427.

Paul, E., Liu, Q.-S., Liu, Y. 2012. Reduction of Excess Sludge Production Using Ozonation or Chlorination: Performance and Mechanisms of Action. in: Biological Sludge

Minimization and Biomaterials/Bioenergy Recovery Technologies, John Wiley \& Sons, Inc., pp. 209-248.

Phan, H.V., Hai, F.I., Zhang, R., Kang, J., Price, W.E., Nghiem, L.D. 2016. Bacterial community dynamics in an anoxic-aerobic membrane bioreactor - Impact on nutrient and trace organic contaminant removal. Int Biodeter Biodegrad, 109, 61-72.

Qiang, Z., Nie, Y., Ben, W., Qu, J., Zhang, H. 2013. Degradation of endocrine-disrupting chemicals during activated sludge reduction by ozone. Chemosphere, 91, 366-373.

Qiang, Z., Wang, L., Dong, H., Qu, J. 2015. Operation performance of an A/A/O process coupled with excess sludge ozonation and phosphorus recovery: A pilot-scale study. Chem Eng J, 268, 162-169.

Qin, M., Molitor, H., Brazil, B., Novak, J.T., He, Z. 2016. Recovery of nitrogen and water from landfill leachate by a microbial electrolysis cell-forward osmosis system. Bioresource Technol, 200, 485-492.

Rai, C.L., Sivasamy, A., Rekha, S. 2013. Ultrasonic sludge disintegration in the presence of iron (II) as catalyst. Int J Environ Waste Manage, 12, 65-76.

Richardson, E.E., Hanson, A., Hernandez, J. 2009. Ozonation of Continuous-Flow Activated Sludge for Reduction of Waste Solids. Ozone Sci Eng, 31, 247-256.

Romero, P., Coello, M.D., Aragón, C.A., Battistoni, P., Eusebi, A.L. 2015. Sludge Reduction through Ozonation: Effects of Different Specific Dosages and Operative Management Aspects in a Full-Scale Study. Journal of Environmental Engineering (United States), 141.

Rossetti, S., Tomei, M.C., Nielsen, P.H., Tandoi, V. 2005. "Microthrix parvicella", a filamentous bacterium causing bulking and foaming in activated sludge systems: a review of current knowledge. FEMS Microbiol Rev, 29, 49-64.

Saktaywin, W., Tsuno, H., Nagare, H., Soyama, T. 2006. Operation of a new sewage treatment process with technologies of excess sludge reduction and phosphorus recovery. in: Water Sci Technol, Vol. 53, pp. 217-227. 
Saktaywin, W., Tsuno, H., Nagare, H., Soyama, T., Weerapakkaroon, J. 2005. Advanced sewage treatment process with excess sludge reduction and phosphorus recovery. Water Res, 39, 902-910.

Schroeder, J.P., Croot, P.L., Von Dewitz, B., Waller, U., Hanel, R. 2011. Potential and limitations of ozone for the removal of ammonia, nitrite, and yellow substances in marine recirculating aquaculture systems. Aquacult Eng, 45, 35-41.

Semblante, G.U., Hai, F.I., Bustamante, H., Guevara, N., Price, W.E., Nghiem, L.D. 2016. Biosolids reduction by the oxic-settling-anoxic process: Impact of sludge interchange rate. Bioresource Technol.

Semblante, G.U., Hai, F.I., Bustamante, H., Guevara, N., Price, W.E., Nghiem, L.D. 2015a. Effects of iron salt addition on biosolids reduction by oxic-settling-anoxic (OSA) process. Int Biodeter Biodegrad, 104, 391-400.

Semblante, G.U., Hai, F.I., Huang, X., Ball, A.S., Price, W.E., Nghiem, L.D. 2015b. Trace organic contaminants in biosolids: Impact of conventional wastewater and sludge processing technologies and emerging alternatives. J Hazard Mater, 300, 1-17.

Semblante, G.U., Hai, F.I., Ngo, H.H., Guo, W., You, S.-J., Price, W.E., Nghiem, L.D. 2014a. Sludge cycling between aerobic, anoxic and anaerobic regimes to reduce sludge production during wastewater treatment: Performance, mechanisms, and implications. Bioresource Technol, 155, 395-409.

Semblante, G.U., Hai, F.I., Ngo, H.H., Guo, W., You, S.-J., Price, W.E., Nghiem, L.D. 2014b. Sludge cycling between aerobic, anoxic and anaerobic regimes to reduce sludge production during wastewater treatment: Performance, mechanisms, and implications. Bioresour. Technol, 155, 395-409.

Seo, S.H., Sung, B.W., Kim, G.J., Chu, K.H., Um, C.Y., Yun, S.L., Ra, Y.H., Ko, K.B. 2010. Removal of heavy metals in an abandoned mine drainage via ozone oxidation: A pilotscale operation. Water Sci Technol, 62, 2115-2120.

Smith, S.R. 2009. Organic contaminants in sewage sludge (biosolids) and their significance for agricultural recycling. Philo Trans $R$ Soc A, 367, 4005-4041.

Snyder, S.A., Wert, E.C., Rexing, D.J., Zegers, R.E., Drury, D.D. 2006. Ozone Oxidation of Endocrine Disruptors and Pharmaceuticals in Surface Water and Wastewater. Ozone Sci Eng, 28, 445-460.

Song, K.-G., Choung, Y.-K., Ahn, K.-H., Cho, J., Yun, H. 2003. Performance of membrane bioreactor system with sludge ozonation process for minimization of excess sludge production. Desalination, 157, 353-359.

Spérandio, M., Paul, E., Bessière, Y., Liu, Y. 2012. Sludge Production: Quantification and Prediction for Urban Treatment Plants and Assessment of Strategies for Sludge Reduction. in: Biological Sludge Minimization and Biomaterials/Bioenergy Recovery Technologies, John Wiley \& Sons, Inc., pp. 81-116.

Stendahl, K., Jäfverström, S. 2004. Recycling of sludge with the Aqua Reci process. in: Water Sci Technol, Vol. 49, pp. 233-240.

Su, C., Li, W., Lu, Y., Chen, M., Huang, Z. 2016. Effect of heterogeneous Fenton-like pretreatment on anaerobic granular sludge performance and microbial community for the treatment of traditional Chinese medicine wastewater. J Hazard Mater, 314, 51-58.

Subha, B., Muthukumar, M. 2012. Optimization of Ozonation Process for the Reduction of Excess Sludge Production from Activated Sludge Process of Sago Industry Wastewater Using Central Composite Design. Scientific World J, 2012, 239271. 
Sui, P., Nishimura, F., Nagare, H., Hidaka, T., Nakagawa, Y., Tsuno, H. 2011. Behavior of inorganic elements during sludge ozonation and their effects on sludge solubilization. Water Res, 45, 2029-2037.

Sui, P., Nishimura, F., Tsuno, H. 2014. Nitrogen behavior during sludge ozonation: a long-term observation by pilot experiments. Water Sci Technol, 70, 289-296.

Suzuki, Y., Kondo, T., Nakagawa, K., Tsuneda, S., Hirata, A., Shimizu, Y., Inamori, Y. 2006. Evaluation of sludge reduction and phosphorus recovery efficiencies in a new advanced wastewater treatment system using denitrifying polyphosphate accumulating organisms. in: Water Sci Technol, Vol. 53, pp. 107-113.

Tchobanoglus, G., Burton, F., Stensel, H. 2003. Wastewater engineering: Treatment and reuse. American Water Works Association, New York.

Tsuno, H., Arakawa, K., Kato, Y., Nagare, H. 2008. Advanced Sewage Treatment with Ozone Under Excess Sludge Reduction, Disinfection and Removal of EDCs. Ozone Sci Eng, 30, 238-245.

Turovskiy, I.S., Mathai, P.K. 2005. Sludge Quantities and Characteristics. in: Wastewater Sludge Processing, John Wiley \& Sons, Inc., pp. 30-59.

Tyagi, V.K., Lo, S.-L. 2013. Sludge: A waste or renewable source for energy and resources recovery? Renew Sust Energ Rev, 25, 708-728.

Umar, M., Roddick, F., Fan, L., Aziz, H.A. 2013. Application of ozone for the removal of bisphenol A from water and wastewater - A review. Chemosphere, 90, 2197-2207.

Vaiopoulou, E., Misiti, T.M., Pavlostathis, S.G. 2015. Removal and toxicity reduction of naphthenic acids by ozonation and combined ozonation-aerobic biodegradation. Bioresource Technol, 179, 339-347.

von Gunten, U. 2003a. Ozonation of drinking water: Part I. Oxidation kinetics and product formation. Water Res, 37, 1443-1467.

von Gunten, U. 2003b. Ozonation of drinking water: Part II. Disinfection and by-product formation in presence of bromide, iodide or chlorine. Water Res, 37, 1469-1487.

Wang, H., Ren, Z.J. 2014. Bioelectrochemical metal recovery from wastewater: A review. Water Res, 66, 219-232.

Wei, Y., Van Houten, R.T., Borger, A.R., Eikelboom, D.H., Fan, Y. 2003. Minimization of excess sludge production for biological wastewater treatment. Water Res, 37, 4453-4467.

Xie, M., Nghiem, L.D., Price, W.E., Elimelech, M. 2014. Toward Resource Recovery from Wastewater: Extraction of Phosphorus from Digested Sludge Using a Hybrid Forward Osmosis-Membrane Distillation Process. Environ Sci Technol Lett, 1, 191-195.

Yan, S.-T., Zheng, H., Li, A., Zhang, X., Xing, X.-H., Chu, L.-B., Ding, G., Sun, X.-L., Jurcik, B. 2009. Systematic analysis of biochemical performance and the microbial community of an activated sludge process using ozone-treated sludge for sludge reduction. Bioresource Technol, 100, 5002-5009.

Yang, S.-S., Guo, W.-Q., Meng, Z.-H., Zhou, X.-J., Feng, X.-C., Zheng, H.-S., Liu, B., Ren, N.Q., Cui, Y.-S. 2013. Characterizing the fluorescent products of waste activated sludge in dissolved organic matter following ultrasound assisted ozone pretreatments. Bioresource Technol, 131, 560-563.

Yuan, X., Huang, H., Zeng, G., Li, H., Wang, J., Zhou, C., Zhu, H., Pei, X., Liu, Z., Liu, Z. 2011. Total concentrations and chemical speciation of heavy metals in liquefaction residues of sewage sludge. Bioresource Technol, 102, 4104-4110. 
Zhang, F., Li, J., He, Z. 2014. A new method for nutrients removal and recovery from wastewater using a bioelectrochemical system. Bioresource Technol, 166, 630-634.

Zhang, G., Yang, J., Liu, H., Zhang, J. 2009. Sludge ozonation: Disintegration, supernatant changes and mechanisms. Bioresource Technol, 100, 1505-1509.

Zhou, H., Smith, D.W. 2000. Ozone mass transfer in water and wastewater treatment: experimental observations using a 2D laser particle dynamics analyzer. Water Res, 34, 909-921. 


\section{List of Figures}

Figure 1. Three-dimensional approach to sludge management with ozonation

Figure 2. Schematic diagram of sludge reduction by ozonation of RAS

Figure 3. Factors affecting sludge reduction by ozonation

Figure 4. Sludge reduction at various solids concentrations in laboratory-scale (Richardson et al., 2009; Nie et al., 2014) and full-scale (Tsuno et al., 2008; Gardoni et al., 2011; Romero et al. $\underline{2015}$ ) studies. The symbols refer to the following ozone dosages: $\square-64 \mathrm{mg} \mathrm{O}_{3} / \mathrm{g}$ TSS (Richardson et al., 2009); • - 100 mg O 3 /g TSS (Nie et al., 2014); $\boldsymbol{\Delta}-30$ mg O3/g TSS* (Huysmans et al., 2001); - 30 to $40 \mathrm{mg} \mathrm{O}_{3} / \mathrm{g} \mathrm{SS}$ (Tsuno et al., 2008); ○- 30 to $40 \mathrm{mg} \mathrm{O}_{3} / \mathrm{g} \mathrm{SS}$ (Tsuno et al., 2008); $\diamond-30$ to $40 \mathrm{mg} \mathrm{O} 3 / \mathrm{g} \mathrm{SS}$ (Tsuno et al., 2008); $\boldsymbol{\nabla}-0.8$ to $2.5 \mathrm{mg} \mathrm{O} / \mathrm{g} \mathrm{DS}$ (Gardoni et al., 2011); -0.7 to $5 \mathrm{mg} \mathrm{O}_{3} / \mathrm{g}$ DS (Romero et a., 2015). 


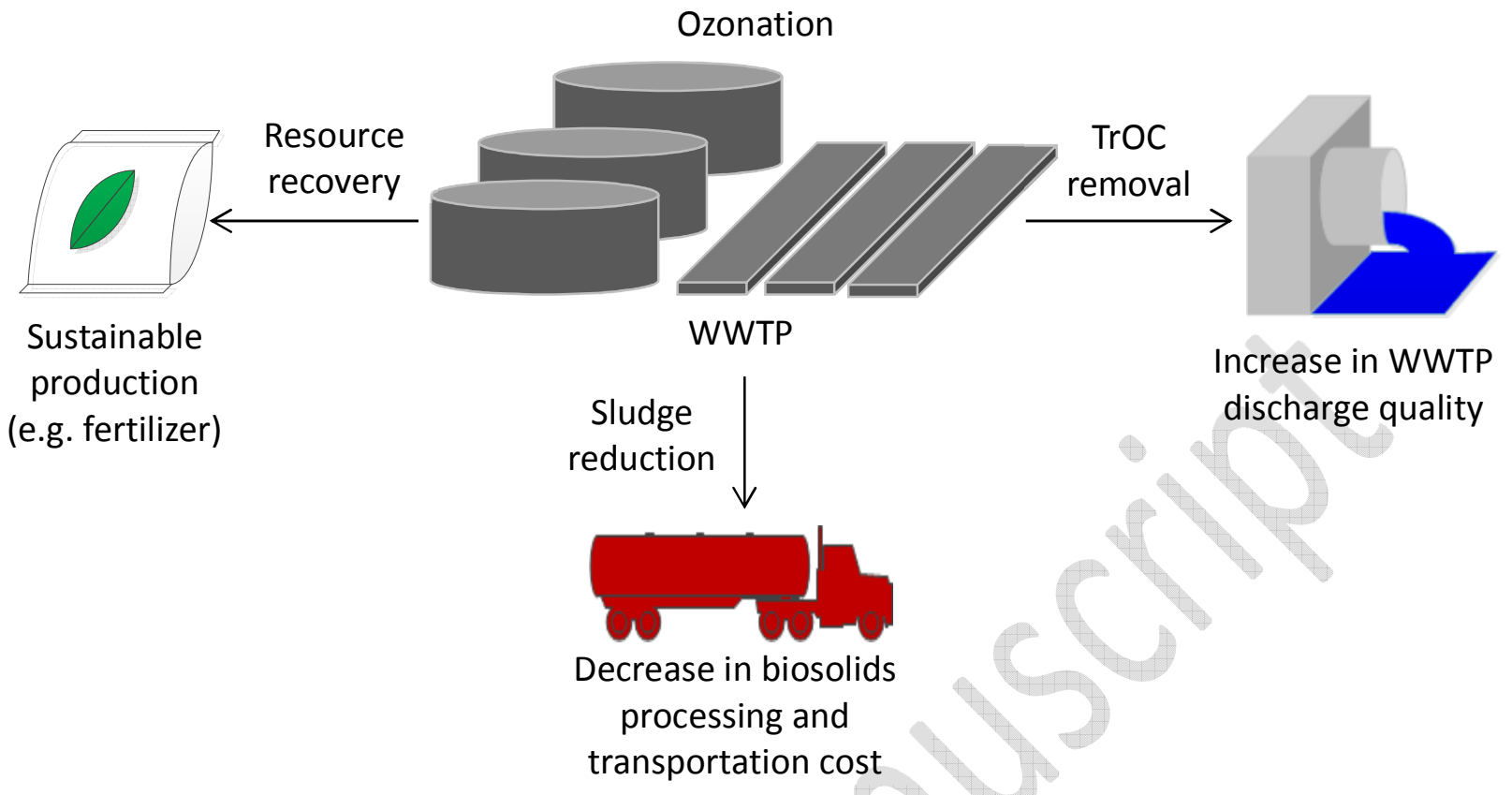

Figure 1. Multidimensional approach to sludge management with ozonation 


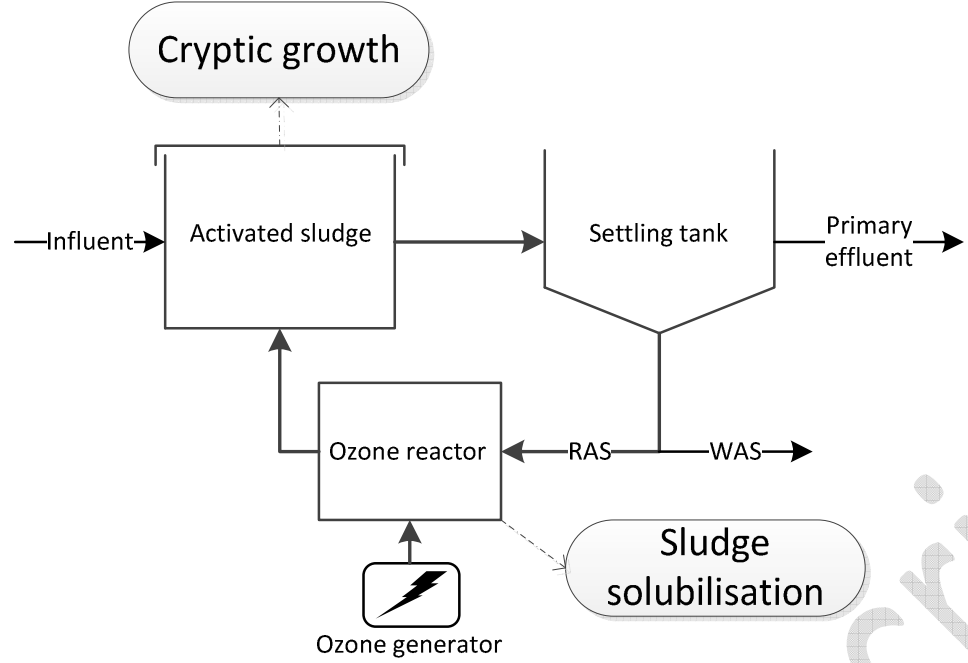

Figure 2. Schematic diagram of sludge reduction by ozonation of RAS 


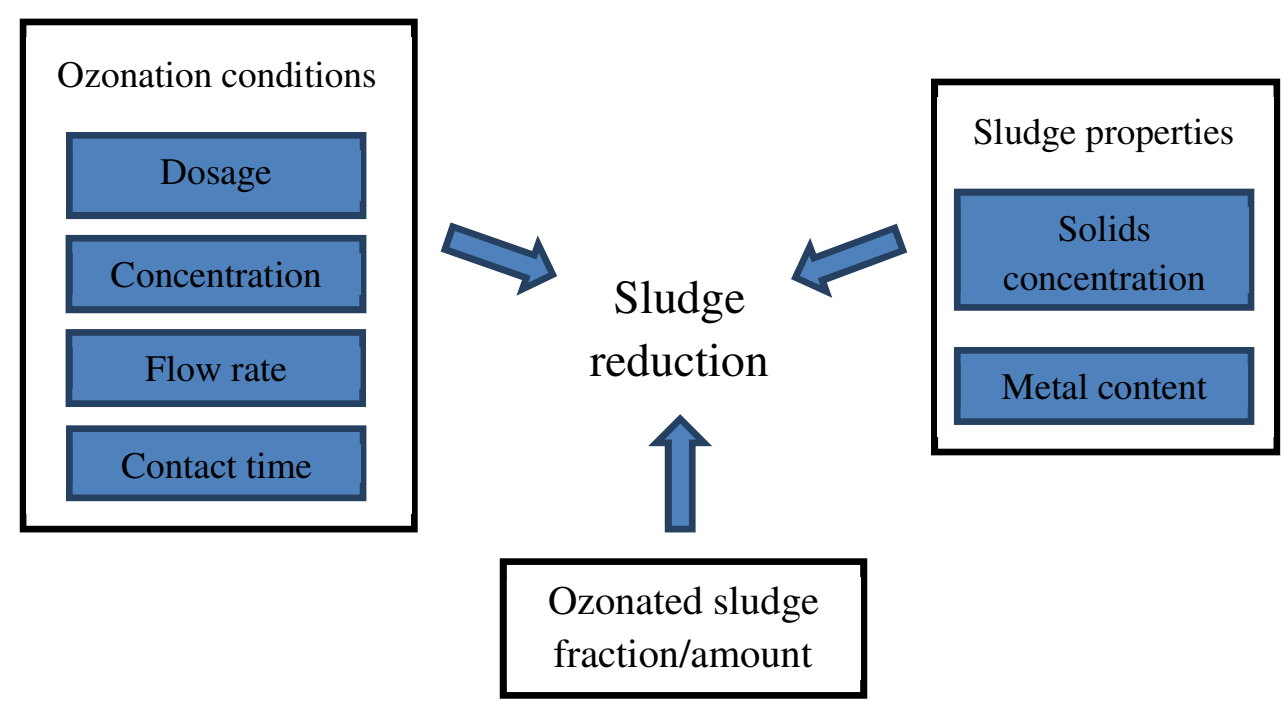

Figure 3. Factors affecting sludge reduction by ozonation 


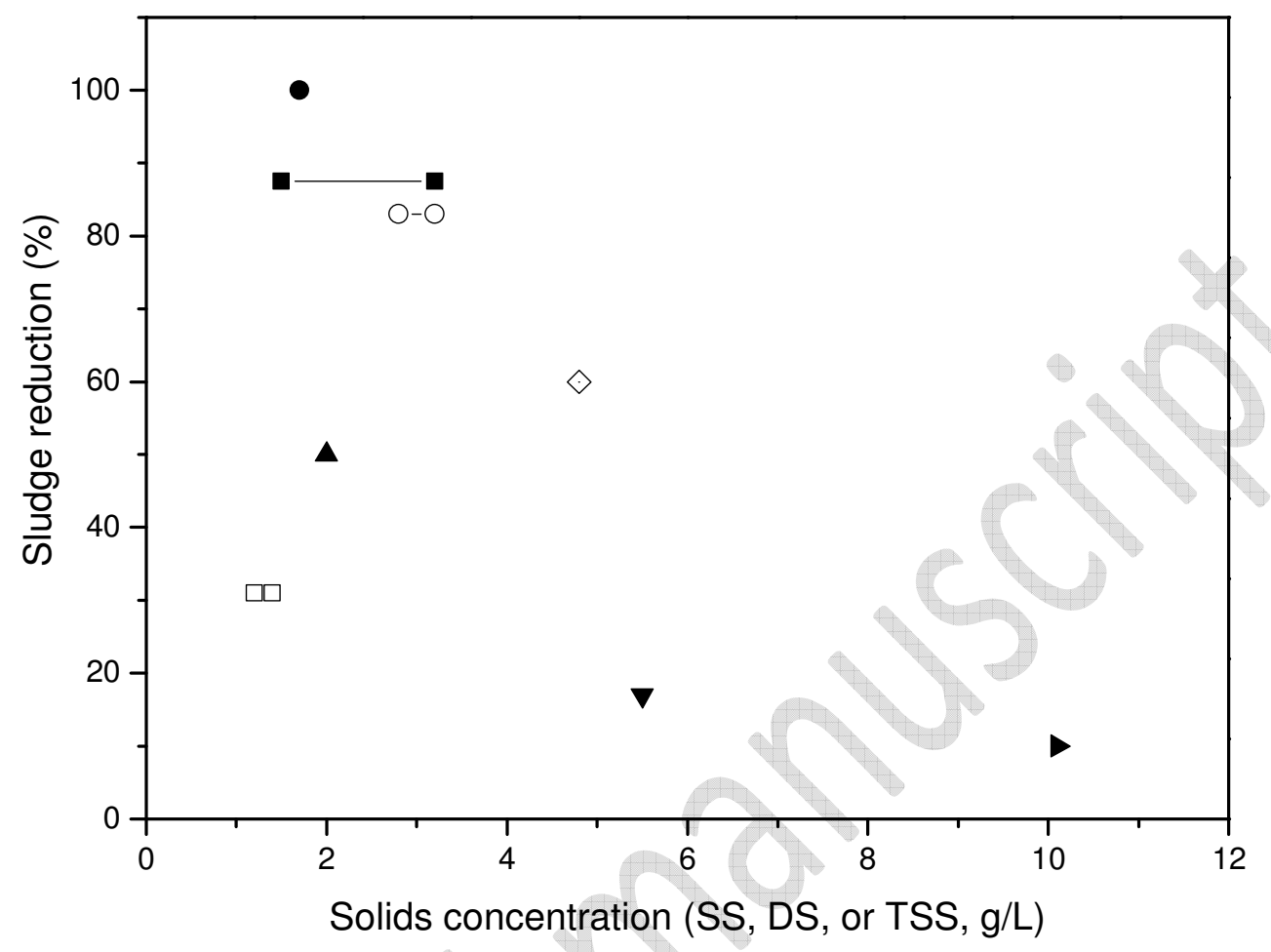

Figure 4. Sludge reduction at various solids concentrations in laboratory-scale (Richardson et al. 2009; Nie et al., 2014) and full-scale (Tsuno et al., 2008; Gardoni et al., 2011; Romero et al.,

$\underline{2015}$ ) studies. The symbols refer to the following ozone dosages: $\square-64 \mathrm{mg} \mathrm{O} / \mathrm{g}$ TSS

(Richardson et al., 2009); $-100 \mathrm{mg} \mathrm{O} / \mathrm{g}$ TSS (Nie et al., 2014); $\boldsymbol{\Delta}-30 \mathrm{mg} \mathrm{O} / \mathrm{g}^{2}$ TSS* (Huysmans et al., 2001); - 30 to $40 \mathrm{mg} \mathrm{O}_{3} / \mathrm{g} \mathrm{SS}$ (Tsuno et al., 2008); ○ - 30 to $40 \mathrm{mg} \mathrm{O}_{3} / \mathrm{g} \mathrm{SS}$ (Tsuno et al., 2008); $\diamond-30$ to $40 \mathrm{mg} \mathrm{O} / \mathrm{g}$ SS (Tsuno et al., 2008); $\mathbf{\nabla}-0.8$ to $2.5 \mathrm{mg} \mathrm{O} / \mathrm{g}$ DS (Gardoni et al., 2011); -0.7 to $5 \mathrm{mg} \mathrm{O}_{3} / \mathrm{g}$ DS (Romero et a., 2015). 


\section{List of Tables}

Table 1. Effect of ozone dosage on average sludge floc size

Table 2. Sludge reduction through ozonation of RAS at different ozone dosages

Table 3. Impact of ozone concentration, flow rate, and contact time with sludge on sludge solubilisation and reduction efficiencies

Table 4. Biological nitrogen and phosphorous removal by ozonated reactors at different ozone dosages

Table 5. Impact of ozonation on SVI

Table 6. Removal efficiency of TrOCs from wastewater and sludge through ozonation 
Table 1. Effect of ozone dosage on average sludge floc size

\begin{tabular}{|c|c|}
\hline Ozone dosage & Impact on average floc size \\
\hline $\begin{array}{c}\text { Increase from100 to } 5000 \mathrm{mg} \\
\mathrm{O}_{3} / \mathrm{g} \text { dry solids (DS) }\end{array}$ & Increased from 40 to $70 \mu \mathrm{m}$ \\
\hline $\begin{array}{c}\text { Increase from } 7 \text { to } 60 \mathrm{mg} \mathrm{O}_{3} / \mathrm{g} \\
\text { total solids (TS) }\end{array}$ & Increased from 40 to $70 \mu \mathrm{m}$ \\
\hline $\begin{array}{l}\text { Increase from } 10 \text { to } 16 \mathrm{mg} \\
\qquad \mathrm{O}_{3} / \mathrm{g} \mathrm{TS}\end{array}$ & Bougrier et al. (2006) \\
\hline $\begin{array}{l}\text { Increase from } 28 \text { to } 80 \mathrm{mg} \\
\qquad \mathrm{O}_{3} / \mathrm{g} \mathrm{TS}\end{array}$ & Zhang et al. (2009) \\
\hline $\begin{array}{c}\text { Increase from zero (no } \\
\text { ozonation) to } 100 \mathrm{mg} \mathrm{O}_{3} / \mathrm{g} \\
\text { suspended solids (SS) }\end{array}$ & Decrease from 60 to \\
\hline
\end{tabular}


Table 2. Sludge reduction through ozonation of RAS at different ozone dosages

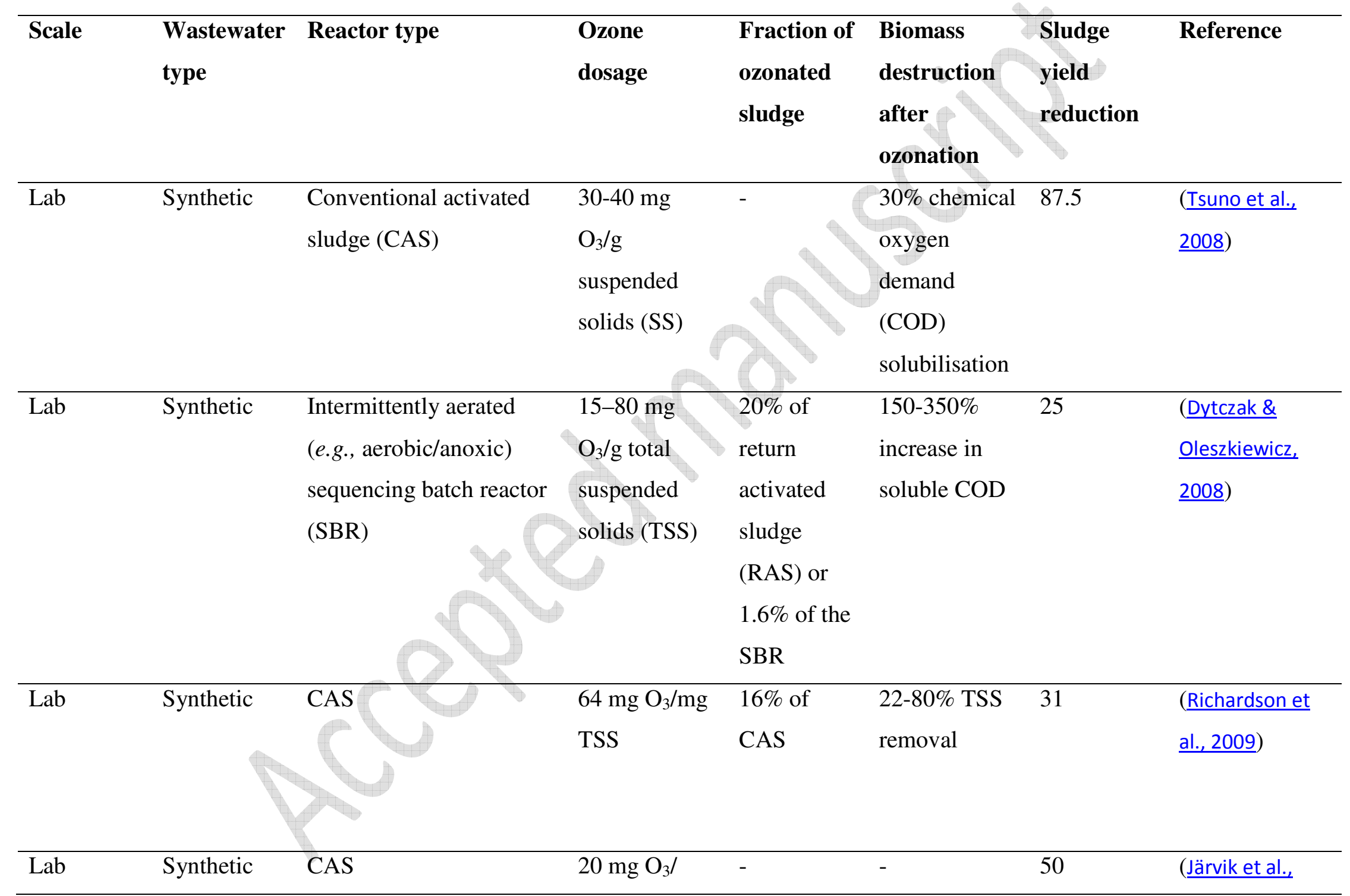




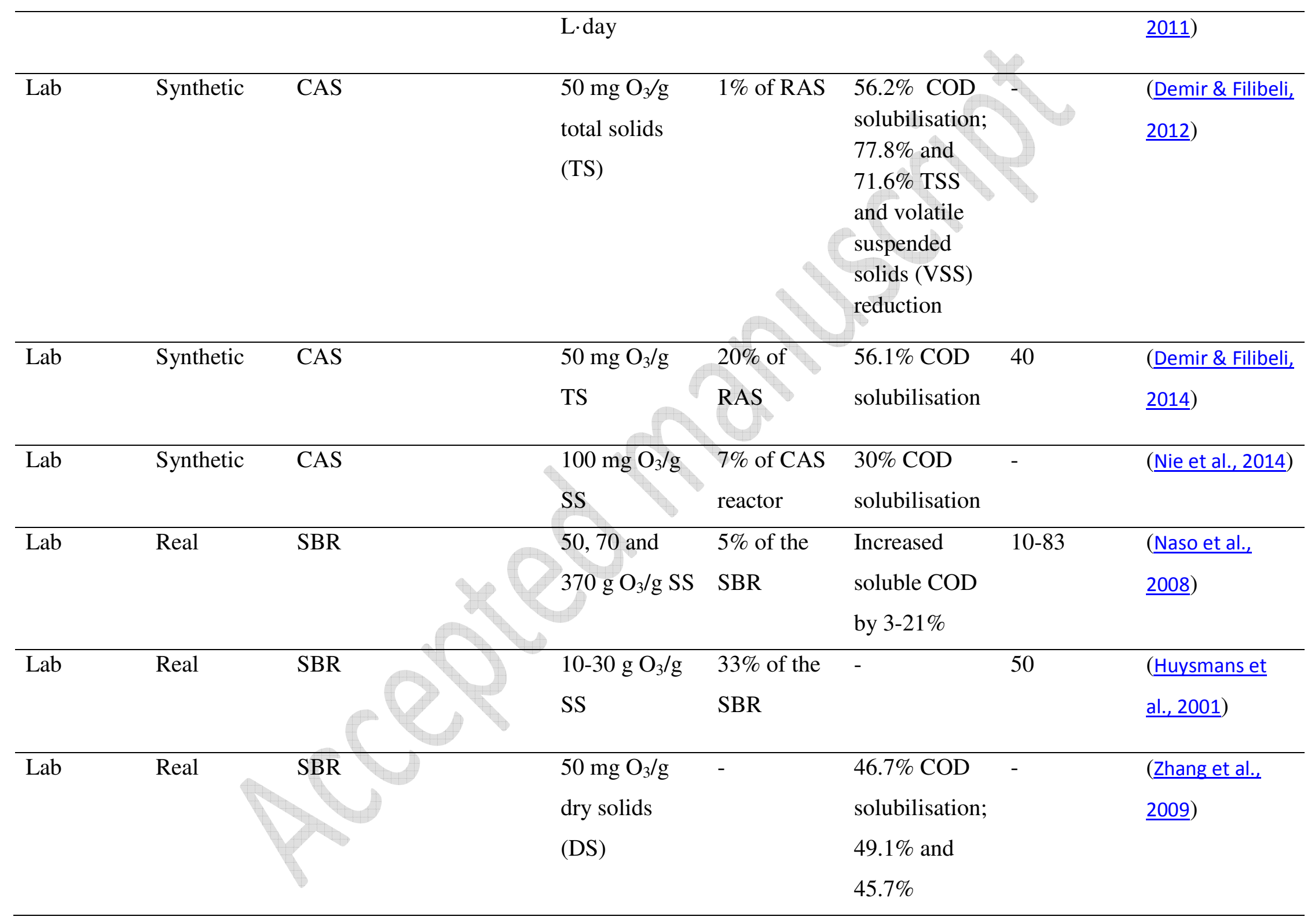




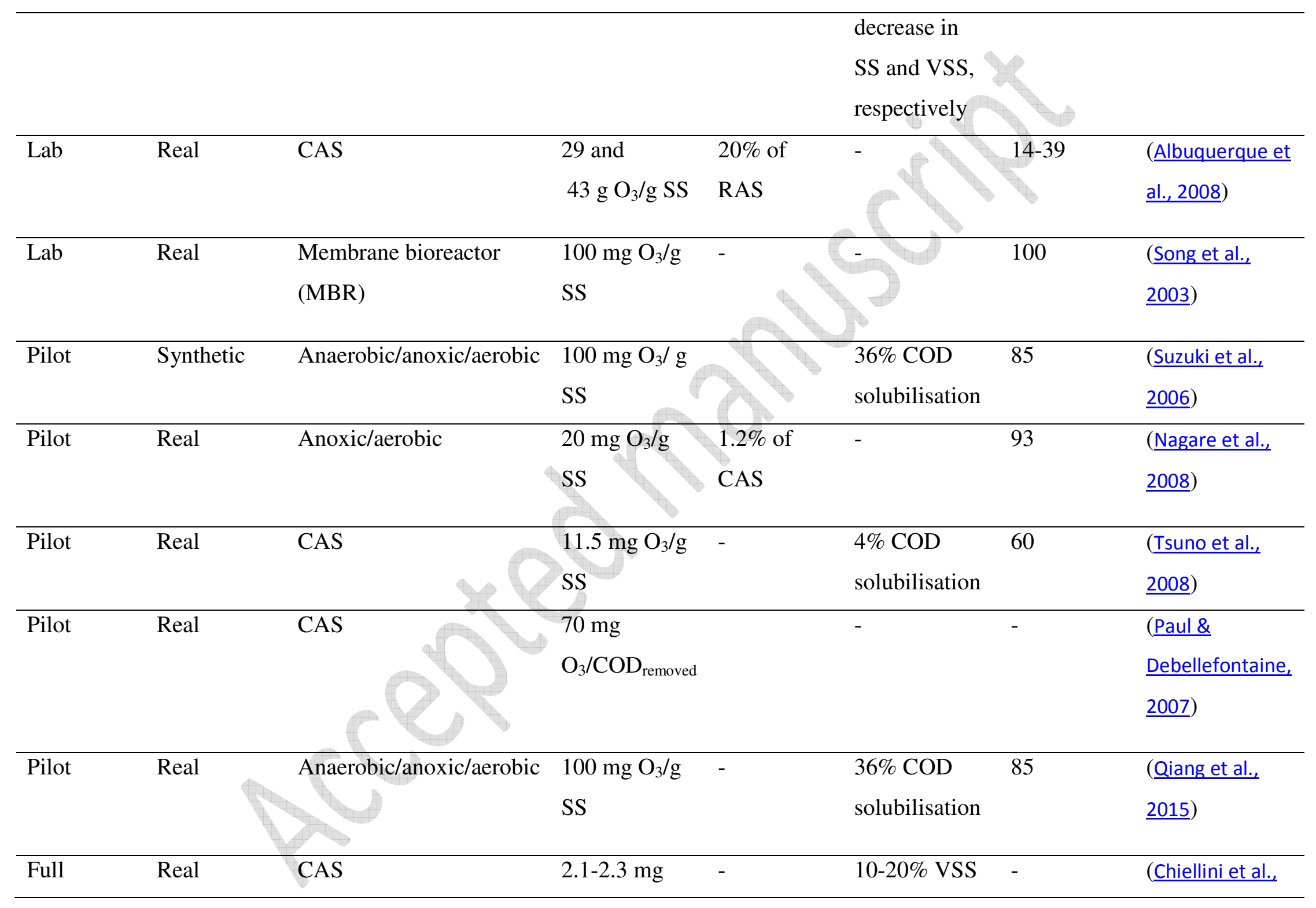




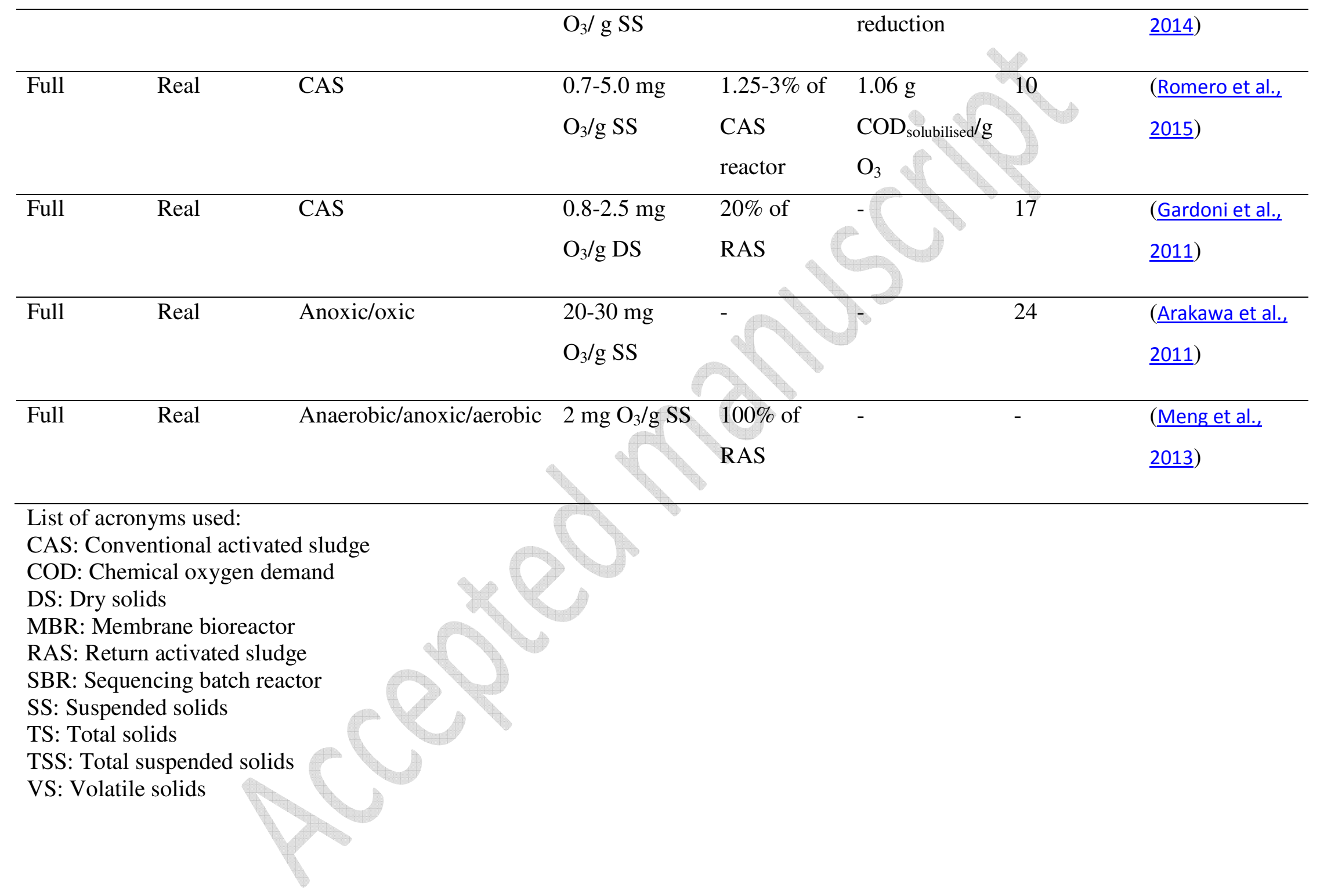


Table 3. Effect of ozone concentration, flow rate, and contact time on sludge solubilisation and reduction efficiency

\begin{tabular}{|c|c|c|c|c|c|c|c|}
\hline $\begin{array}{c}\text { Ozone } \\
\text { concentration } \\
\left(\mathrm{mg} \mathrm{O}_{3} / \mathrm{L}\right)\end{array}$ & $\begin{array}{c}\text { Ozone } \\
\text { flow rate } \\
(\mathrm{L} / \mathrm{min})\end{array}$ & $\begin{array}{c}\text { Contact } \\
\text { time } \\
(\text { min) }\end{array}$ & $\begin{array}{l}\text { Ozone } \\
\text { dosage }\end{array}$ & $\begin{array}{c}\text { Sludge } \\
\text { concentration }\end{array}$ & Sludge solubilisation & $\begin{array}{c}\text { Sludge yield } \\
\text { reduction } \\
(\%)\end{array}$ & Reference \\
\hline 30 & - & $10-15$ & $\begin{array}{c}0.029- \\
0.043 \mathrm{~g} \\
\mathrm{O}_{3} / \mathrm{SS}\end{array}$ & - & & 39 & $\frac{\text { (Albuquerque et }}{\text { al., 2008) }}$ \\
\hline 44.7 & 11.8 & - & $\begin{array}{c}20-30 \mathrm{mg} \\
\mathrm{O}_{3} / \mathrm{g} \mathrm{SS}\end{array}$ & $2.85 \mathrm{~g} \mathrm{SS} / \mathrm{L}$ & & 24 & $\frac{(\text { Arakawa et al., }}{\underline{2011})}$ \\
\hline- & 0.005 & $5-20$ & $\begin{array}{l}15-80 \mathrm{mg} \\
\mathrm{O}_{3} / \mathrm{mg} \mathrm{SS}\end{array}$ & $1.80 \mathrm{mg} \mathrm{SS} / \mathrm{L}$ & $\begin{array}{l}150-350 \% \text { increase in } \\
\text { COD }\end{array}$ & 25 & $\begin{array}{l}\frac{(\text { Dytczak \& }}{\underline{\text { Oleszkiewicz, }}} \\
\underline{2008)}\end{array}$ \\
\hline- & - & 5 & $\begin{array}{l}1500- \\
3000 \\
\mathrm{mg} \mathrm{O}_{3} / \mathrm{g} \\
\mathrm{TSS}\end{array}$ & $2-12 \mathrm{~g}$ TSS /L & - & 17 & $\frac{\text { (Gardoni et al., }}{\underline{2015} \text { ) }}$ \\
\hline 0.033 & 3.33 & $\sim 3.6$ & $\begin{array}{c}20 \mathrm{mg} \\
\mathrm{O}_{3} / \mathrm{g} \mathrm{SS}\end{array}$ & $2 \mathrm{~g} \mathrm{SS} / \mathrm{L}$ & - & 51 & $\frac{\text { (Huysmans et al. }}{\underline{2001} \text { ) }}$ \\
\hline 20 & 0.4 & - & $\begin{array}{c}30-40 \mathrm{mg} \\
\mathrm{O}_{3} / \mathrm{g} \mathrm{SS}\end{array}$ & $1.2-4.0 \mathrm{~g} \mathrm{SS} / \mathrm{L}$ & 4-8 g COD solubilised $/ \mathrm{g} \mathrm{O}_{3}$ & 93 & $\frac{(\text { Nagare et al., }}{\underline{2008)}}$ \\
\hline 6.15 & - & & $\begin{array}{c}30-40 \mathrm{mg} \\
\mathrm{O}_{3} / \mathrm{g} \mathrm{SS}\end{array}$ & $\begin{array}{c}1.5-3.2 \mathrm{~g} \\
\mathrm{TSS} / \mathrm{L}\end{array}$ & $30 \%$ COD solubilisation & 87.5 & $\frac{\text { (Tsuno et al. }}{\underline{2008)}}$ \\
\hline 11.3 & - & $8.6^{*}$ & $\begin{array}{l}11.5 \mathrm{mg} \\
\mathrm{O}_{3} / \mathrm{g} \mathrm{SS}\end{array}$ & $\begin{array}{c}4.8-5.3 \mathrm{~g} \\
\mathrm{TSS} / \mathrm{L}\end{array}$ & 4\% COD solubilisation & 60 & $\frac{\text { (Tsuno et al., }}{\underline{2008)}}$ \\
\hline 20 & 0.18 & 240 & $0.13 \mathrm{mg}$ & $1.8 \mathrm{~g}$ TSS $/ \mathrm{L}$ & - & 31 & (Richardson et al., \\
\hline
\end{tabular}




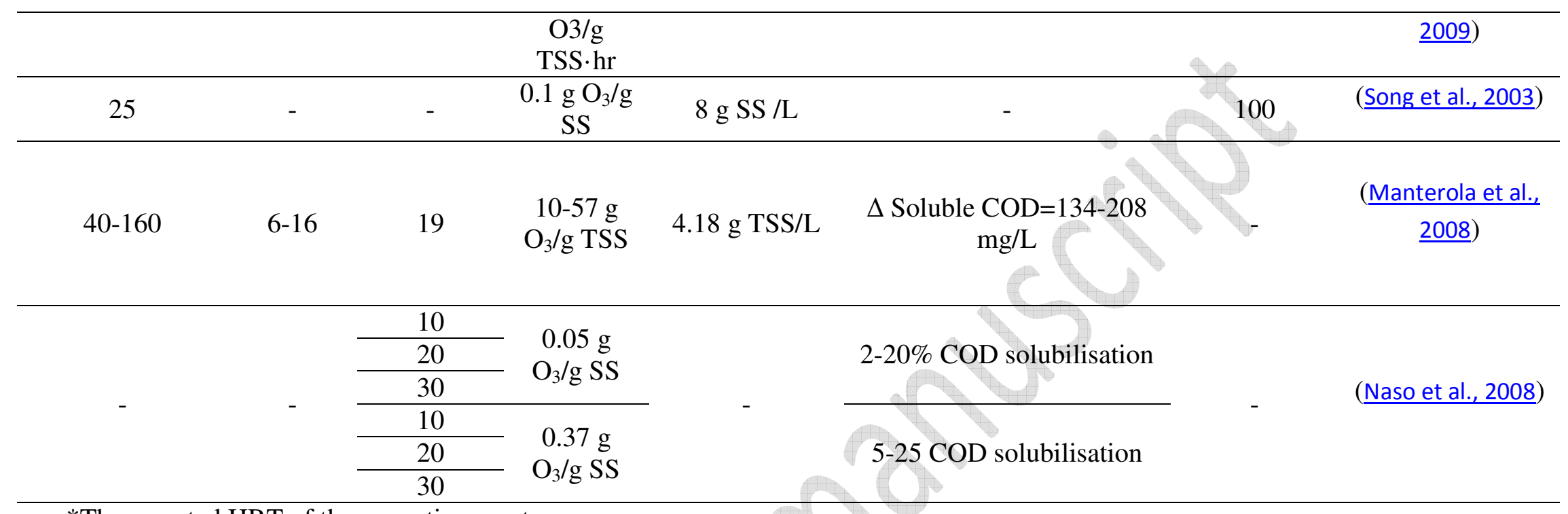

*The reported HRT of the ozonation reactor. 
Table 4. Biological nitrogen and phosphorous removal by ozonated reactors at different ozone dosages

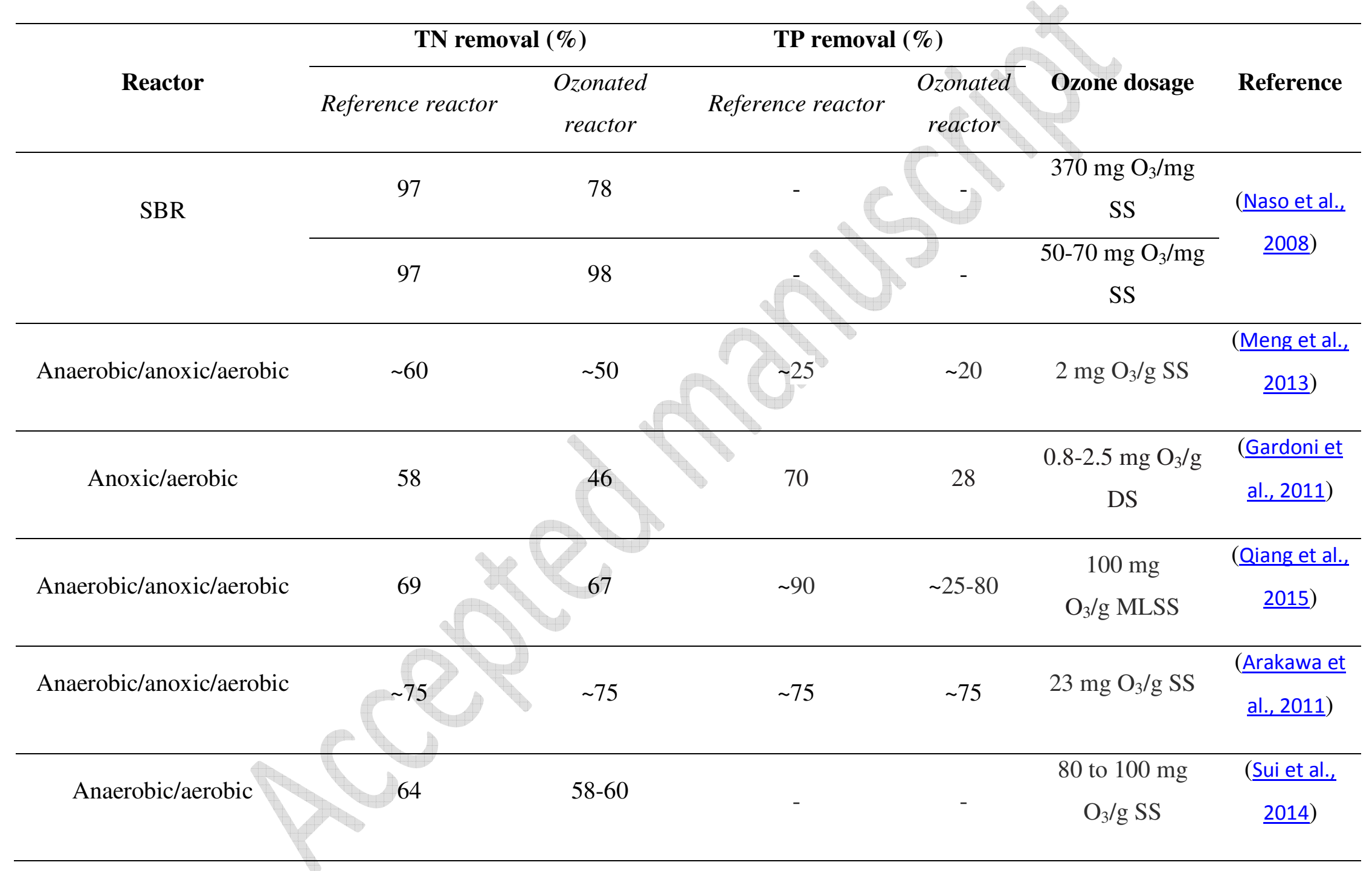




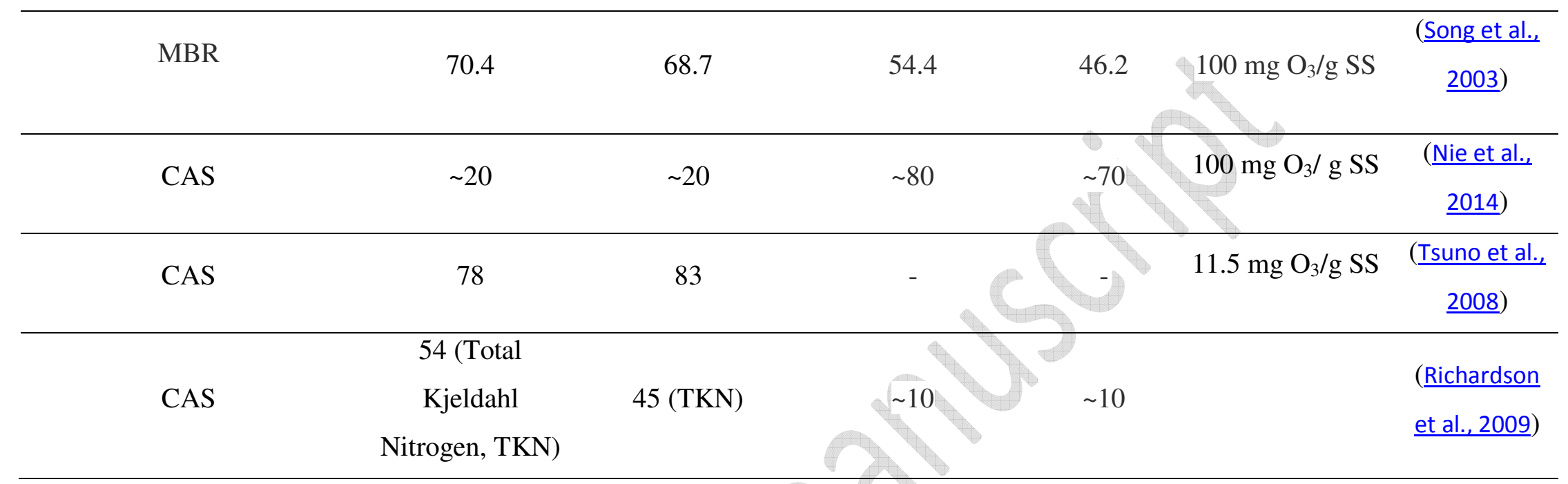


Table 5. Impact of ozonation on SVI

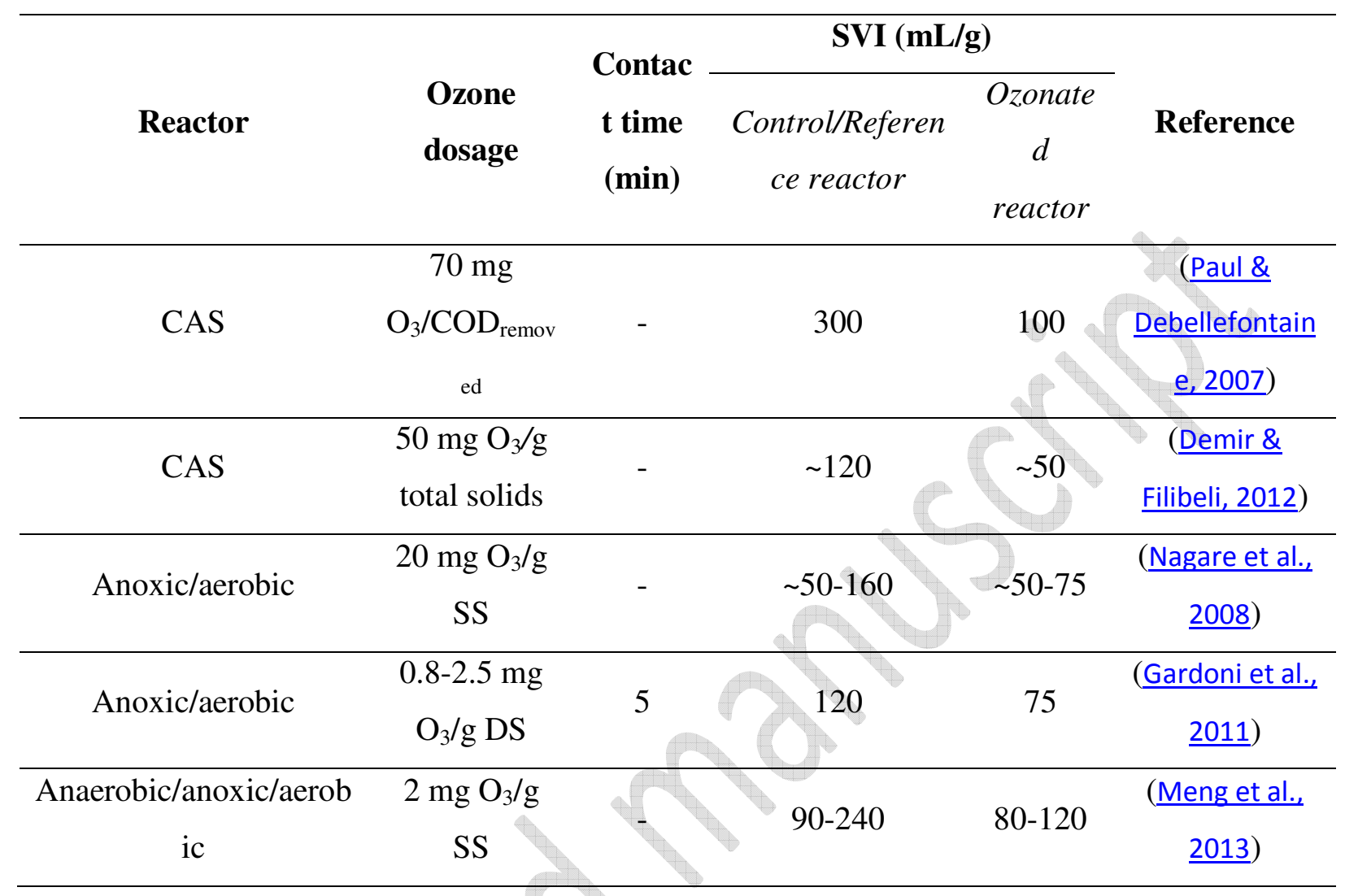


Table 6. Removal efficiency of TrOCs from wastewater and sludge through ozonation

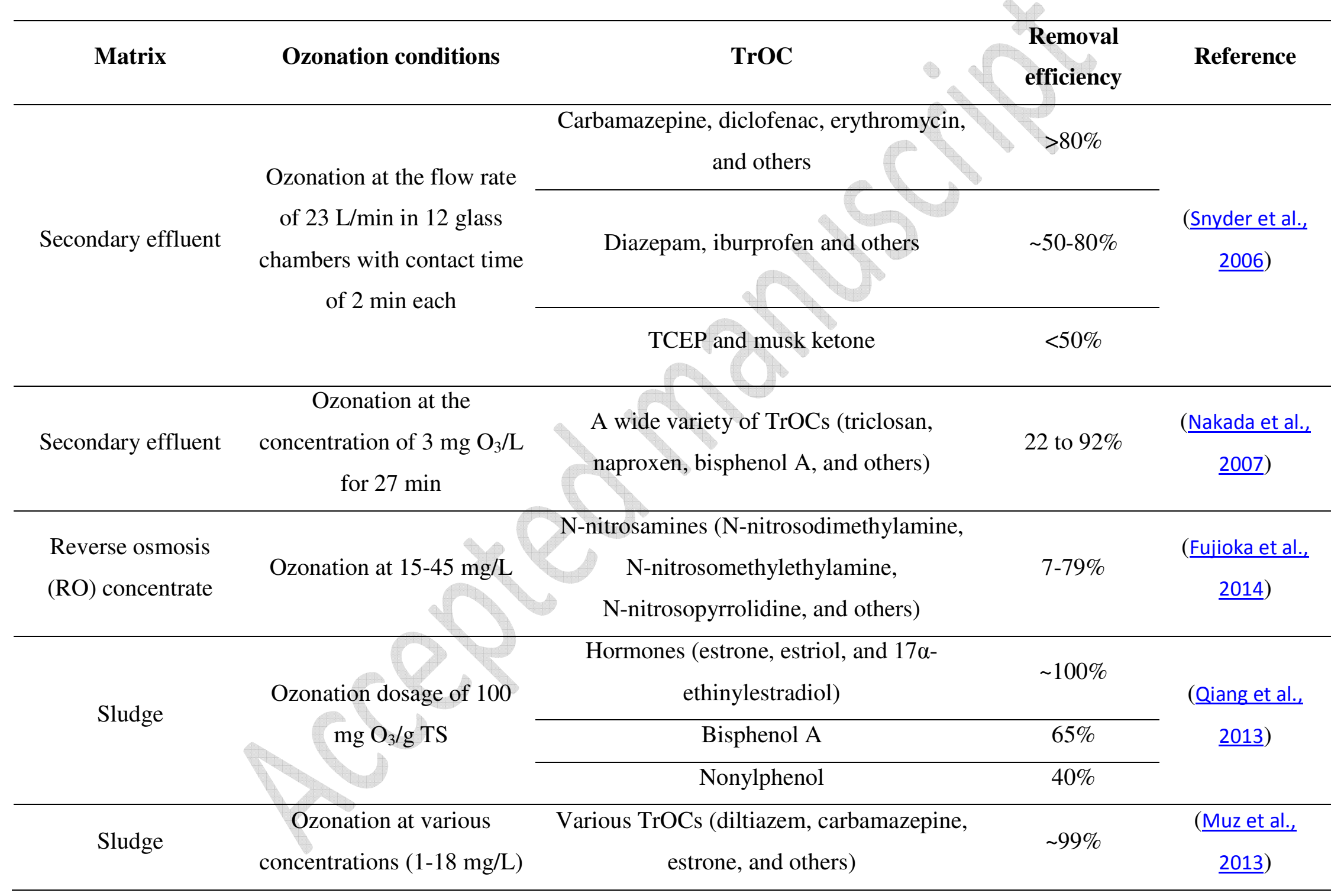


and contact times (6-150

$\min$ )

\begin{tabular}{ccccc}
\hline $\begin{array}{c}\text { Sludge (from a } \\
\text { continuous CAS with } \\
\text { sludge reduction) }\end{array}$ & Ozonation at the dosage of & Various TrOCs & 100\% & (Tsuno et al., \\
\hline $\begin{array}{c}\text { Sludge (from a } \\
\text { continuous CAS with } \\
\text { sludge reduction) }\end{array}$ & $\begin{array}{c}11.5 \mathrm{mg} \mathrm{O}_{3} / \mathrm{g} \mathrm{SS} \\
\text { Ozonation of RAS at the }\end{array}$ & Various TrOCs (E1, E2, EE2, E3) & $81-99 \%$ \\
\cline { 2 - 4 } & & Bisphenol A & (Nie et al., \\
\cline { 3 - 4 }
\end{tabular}




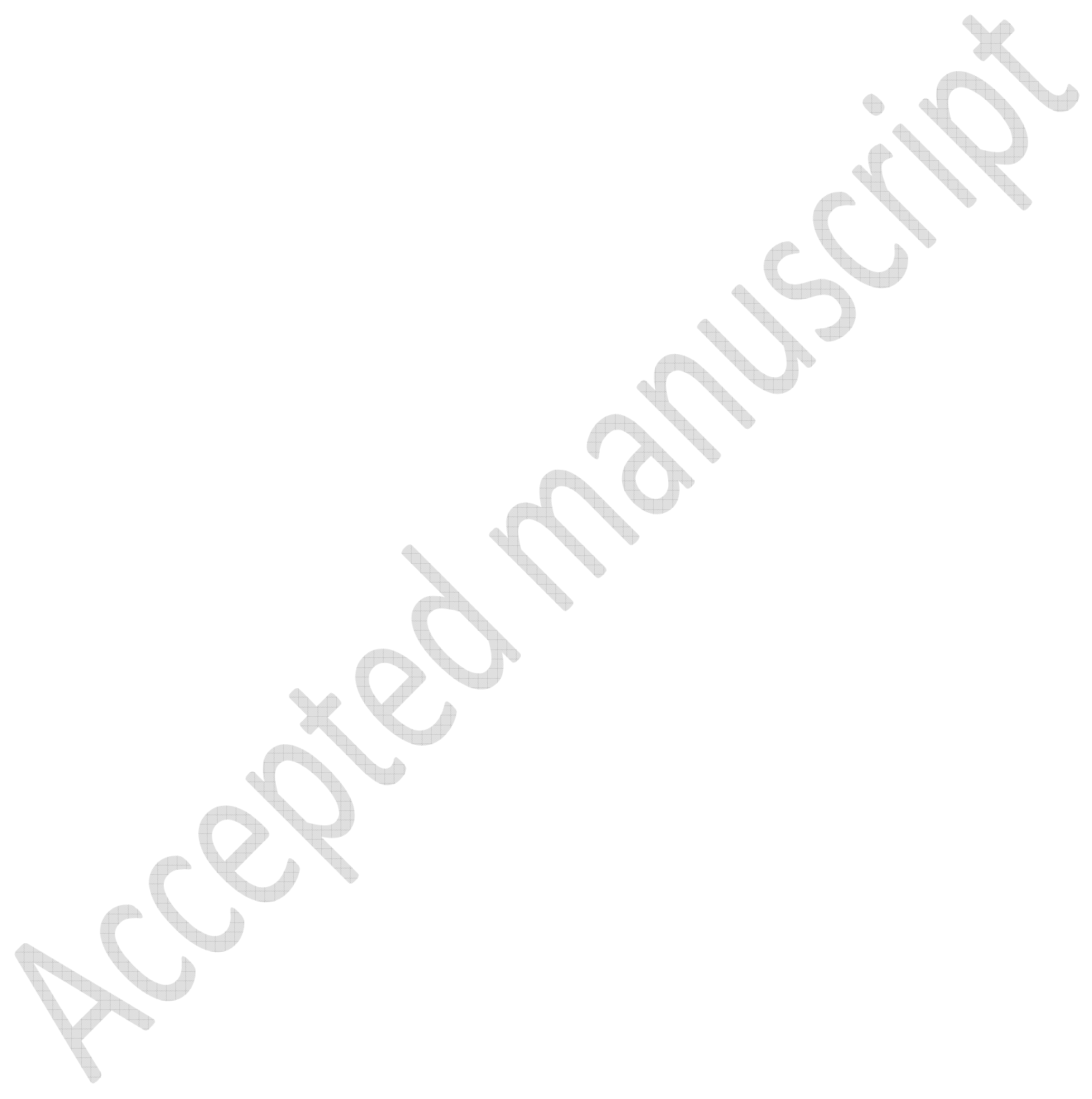

